\title{
Review of Sensors for the In Situ Chemical Characterization of the Hanford Underground Storage Tanks
}

Kevin R. Kyle and Eric L. Mayes

KADEVED

July 29, 1994

JUL 18993

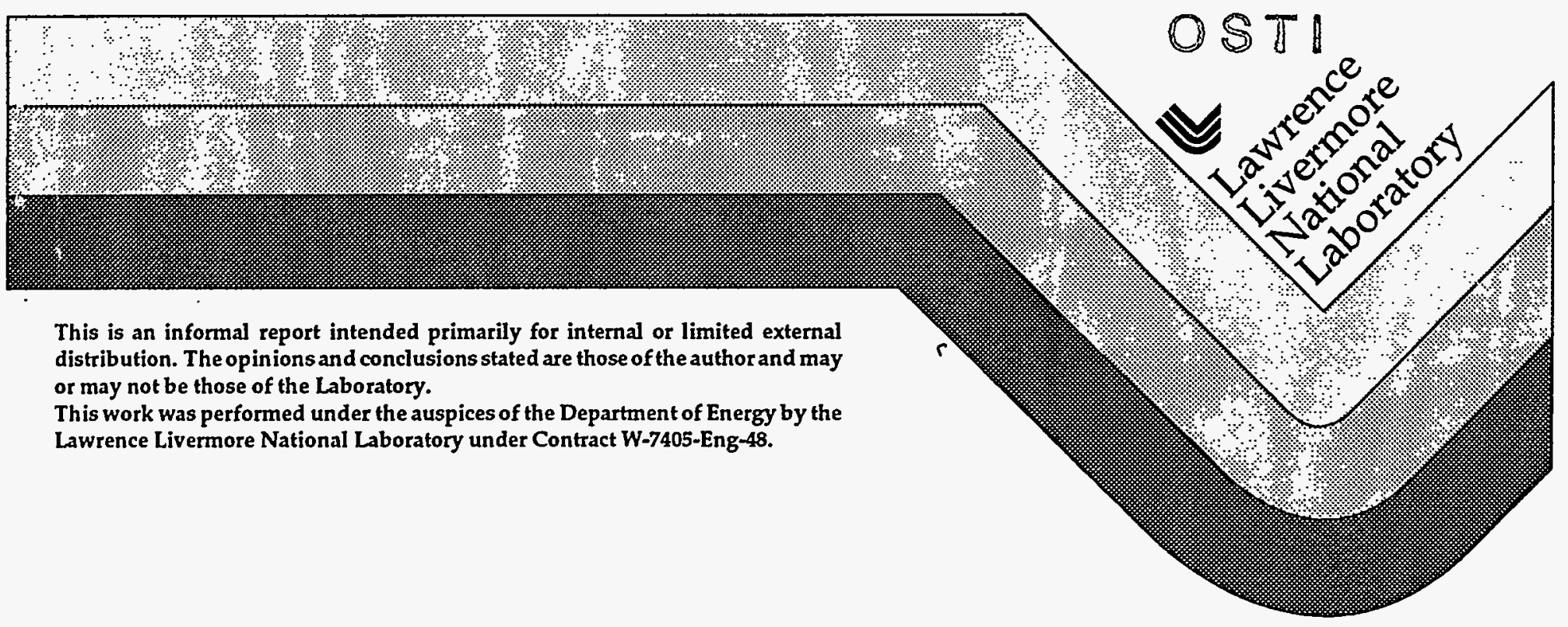

MASTIPR 


\section{DISCLAIMER}

This document was prepared as an account of work sponsored by an agency of the United States Government. Neither the United States Government nor the University of California nor any of their employees, makes any warranty, express or implied, or assumes any legal liability or responsibility for the accuracy, completeness, or usefulness of any information, apparatus, product, or process disclosed, or represents that its use would not infringe privately owned rights. Reference herein to any specific commercial product, process, or service by trade name, trademark manufacturer, or otherwise, does not necessarily constitute or imply its endorsement, recommendation, or favoring by the United States Government or the University of California. The views and opinions of authors expressed herein do not necessarily state or reflect those of the United States Government or the University of California, and shall not be used for advertising or product endorsement purposes.

This report has been reproduced directly from the best available copy.

Available to DOE and DOE contractors from the Office of Scientific and Technical Information P.O. Box 62, Oak Ridge, TN 37831

Prices available from (615) 576-8401, FTS 626-8401

Available to the public from the National Technical Information Service

U.S. Department of Commerce

5285 Port Royal Rd.

Springfield, VA 22161 


\section{DISCLAIMER}

Portions of this document may be illegible in electronic image products. Images are produced from the best available original document. 


\title{
REVIEW of SENSORS \\ for the \\ IN SITU CHEMICAL CHARACTERIZATION \\ of the \\ HANFORD UNDERGROUND STORAGE TANKS
}

July 29, 1994

\begin{abstract}
Kevin R. Kyle
Eric L. Mayes

Characterization and Detection Section

Environmental Technologies Program

Lawrence Livermore National Laboratory
\end{abstract}

This document has been submitted in fulfillment of Milestone Number 3 of the
Technical Task Plan SF-2112-03, "Advanced Fiber Optic Spectroscopy for Inorganic
Contaminants"
Technical Program Manager: 
CONTENTS

1.0 INTRODUCTION $\ldots \ldots \ldots \ldots \ldots \ldots \ldots \ldots \ldots \ldots \ldots \ldots \ldots \ldots \ldots \ldots \ldots$

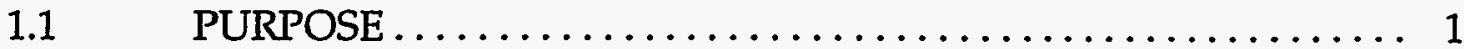

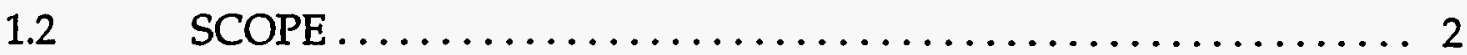

2.0 SENSORS FOR GAS PHASE TANK COMPONENTS $\ldots \ldots \ldots \ldots \ldots ., 3$

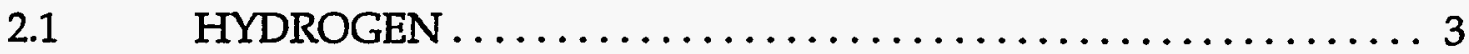

2.1.1 SOLID STATE DEVICES .................... 3

2.1.2 OPTOELECTRONIC DEVICES $\ldots \ldots \ldots \ldots \ldots \ldots \ldots \ldots, 7$

2.1.3 OPTICAL DEVICES $\ldots \ldots \ldots \ldots \ldots \ldots \ldots \ldots \ldots \ldots$

2.2 AMMONIA/AMMONIUM $\ldots \ldots \ldots \ldots \ldots \ldots \ldots \ldots \ldots$

2.2.1 ELECTRONIC DEVICES ..................... 9

2.2.2 OPTICAL DEVICES ........................ 9

2.3 VOLATILE ORGANIC COMPOUNDS (VOC) $\ldots \ldots \ldots \ldots \ldots 10$

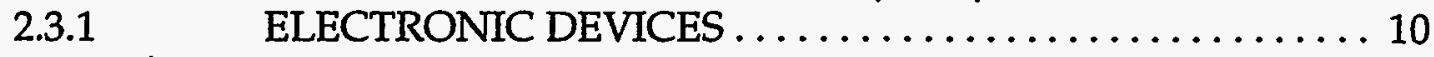

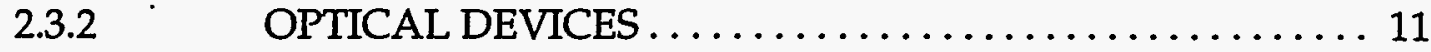

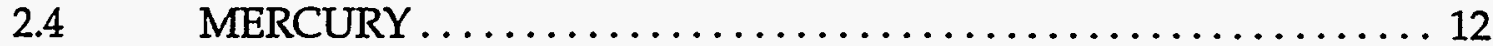

3.0 SENSORS FOR LIQUID AND SOLID PHASE TANK COMPONENTS ... 13

3.1 FERROCYANIDE ION. $\ldots \ldots \ldots \ldots \ldots \ldots \ldots \ldots \ldots \ldots \ldots \ldots \ldots \ldots$

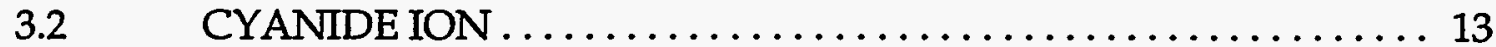

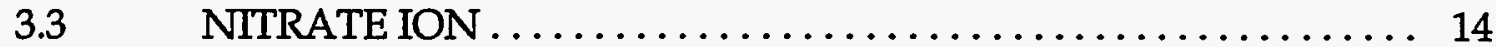

3.3.1 ELECTRODE DEVICES $\ldots \ldots \ldots \ldots \ldots \ldots \ldots \ldots \ldots \ldots \ldots \ldots$

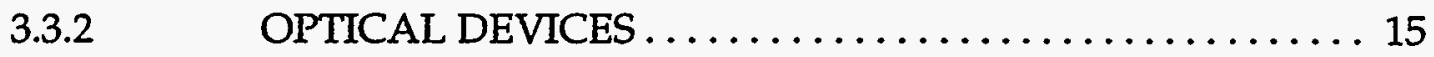

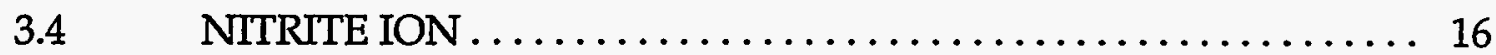

3.5 IONIC SPECIES . . . . . . . . . . . . . . . . . . . . . 16

3.5.1 ELECTRONIC DEVICES . . . . . . . . . . . . . . . . 17

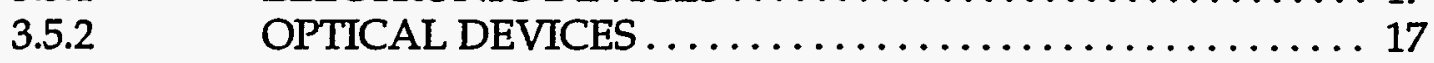

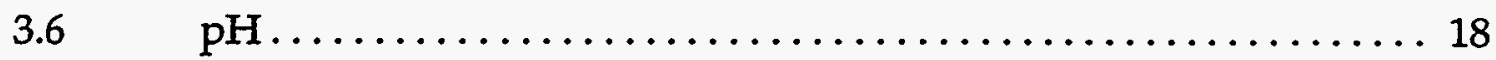

4.0 RADIATION SENSORS. ................................ 19

4.1 TOTAL RADIATION EXPOSURE. . . . . . . . . . . . . . 20

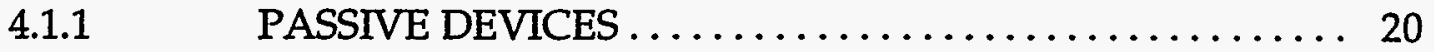

4.1.2 ACTIVE DEVICES . . . . . . . . . . . . . . . . . . . 21

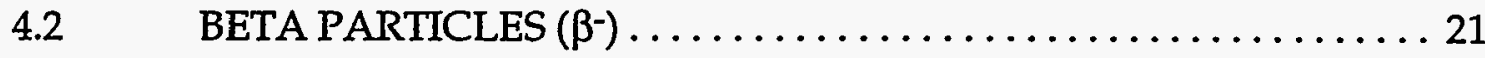

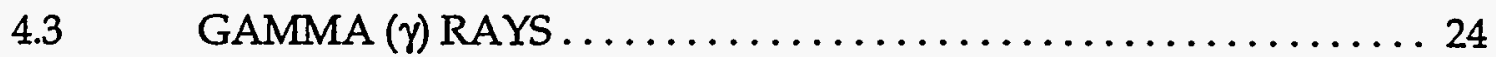

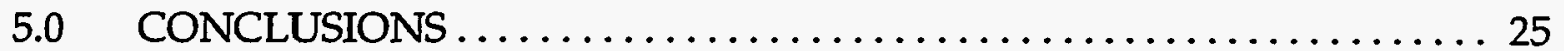

6.0 ACKNOWLEDGMENT $\ldots \ldots \ldots \ldots \ldots \ldots \ldots \ldots \ldots \ldots \ldots \ldots \ldots \ldots \ldots \ldots$

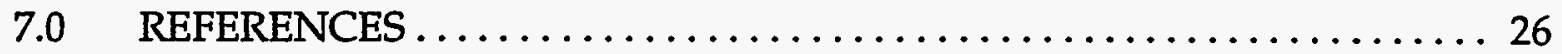


UCRL-ID-118561

page ii of 50

APPENDIX A ISOTOPIC DECAY SCHEMES ................ 36

APPENDIX B DEPARTMENT OF ENERGY MONITORING

41

APPENDIX $C \quad$ COMMERCIALLY AVAILABLE SENSORS ..........446 
UCRL-ID-118561

page 1 of 50

REVIEW of SENSORS for the IN SITU CHEMICAL CHARACTERIZATION of the HANFORD UNDERGROUND STORAGE TANKS

\subsection{INTRODUCTION}

Lawrence Livermore National Laboratory (LLNL), in the Technical Task Plan (TTP) SF-2112-03 subtask 2, is responsible for the conceptual design of a Raman probe for inclusion in the in-tank cone penetrometer. As part of this task, LLNL is assigned the further responsibility of generating a report describing a review of sensor technologies other than Raman that can be incorporated in the in-tank cone penetrometer for the chemical analysis of the tank environment. These sensors would complement the capabilities of the Raman probe, and would give information on gaseous, liquid, and solid state species that are insensitive to Raman interrogation. This work is part of a joint effort involving several DOE laboratories for the design and development of in-tank cone penetrometer deployable systems for direct UST waste characterization at Westinghouse Hanford Company (WHC) under the auspices of the U.S. Department of Energy (DOE) Underground Storage Tank Integrated Demonstration (UST-ID).

\subsection{PURPOSE}

Currently, tank wastes are to be characterized by drilling and physically removing core samples. The cores are analyzed in laboratories in a hot cell environment. The purpose of the cone penetrometer is to bring the interrogative methods to the sample in its native environment, providing faster, safer, and more cost effective tank characterization, both in terms of time and effort. Probes currently exist for the physical characterization of tank wastes in terms of porosity, density, temperature, and electrical conductivity.Q.5 The main tool for chemical analysis in the in-tank cone penetrometer is a fiber optic Raman spectroscopy probe, which will be used to collect information about the main molecular chemical constituents of the tank wastes.

While Raman spectroscopy is a powerful analytical technique for chemically speciating the tank wastes, there exists a need for sensors that provide additional information about the tank environment. Sensors are required that respond quantitatively to specific chemicals, such as metal ions, elemental species, and $\mathrm{pH}$. Additionally, sensors that can monitor toxic or explosive gases and vapors are required. This report details a survey of chemical sensors that can be potentially interfaced with a cone penetrometer for the in situ surveying of the Hanford tank wastes. 


\subsection{SCOPE}

The chemical sensor technologies reviewed in this document meet several requirements for deployment within the Hanford UST environment. First, the technology must be of a size or have the potential to be scaled to fit within a cone penetrometer, which is typically 0.5 to 1.0 inches in inner diameter. Second, the technology should involve no sparks in its interrogation method, nor expose the tank to high voltages capable of sparking. This is required by the existence of potentially explosive atmospheres within the tanks. Technologies based on low potential solid state electronics or optical techniques would best fulfill this second requirement. Third, sensors which require active removal of potentially hazardous tank material for surface stationed analytical processing are not considered. Thus, techniques such as gas chromatography and mass spectroscopy were not included in this report.

The scope of this document includes sensors and technologies which detect and/or monitor the following chemical species:

- Hydrogen $\left(\mathrm{H}_{2}\right)$ : $\quad$ Potential exists for hydrogen concentrations above the lower flammability level (4\%) within the tank headspace and pockets within the porous waste salt cake.

- Ammonia $\left(\mathrm{NH}_{3}, \mathrm{NH}_{4}{ }^{+}\right)$: Concentrations of $0.1 \mathrm{M}$ or $25 \mathrm{ppmV}$ may contribute to toxic tank vapors.

- Volatile Organic Compounds (VOC): Potential exists for the contribution of VOCs to toxic tank vapors, and for the existence of unstable organonitrates.

- $\mathrm{pH}\left(-\log \left[\mathrm{H}^{+}\right.\right.$concentration $\left.]\right)$Potential exists for the corrosion of tank wall materials at $9.5 \leq \mathrm{pH} \leq 12$.

- $\quad$ Ferrocyanide $\left(\mathrm{Fe}(\mathrm{CN})_{6}{ }^{2-}\right): \quad$ Potential exists for the exothermic reaction of ferrocyanide with nitrate. Threshold of concern is $\geq 8 \%$ dry weight basis.

- $\quad$ Cyanide $\left(\mathrm{CN}^{-}\right)$: $\quad$ In the absence of specific ferrocyanide sensors, cyanide can be as an indicator of the potential presence of ferrocyanide.

- Anions, cations: Sensors for detection of heavy metal ions, as well as nitrate/nitrite ratio, and iron as an indicator of ferrocyanide. 
- $\quad{ }^{137} \mathrm{Cs},{ }^{90} \mathrm{Sr}$, and ${ }^{99} \mathrm{Tc}:$

Potential exists for local concentrations of cesium, strontium, and technicium in excess of $1000 \mu \mathrm{Ci} / \mathrm{g}$. The concern is for local heat generation as well as radioactivity.

- $\quad 239,240 \mathrm{Pu}$ and $235,238 \mathrm{U}$ :

Sensors for the identification of TRU wastes. Uranium and plutonium are both radioactive and toxic hazards.

In addition to the literature survey of sensor technologies, this report provides references to additional recent review articles addressing chemical sensors. I.1-I.5 An appendix is included which summarizes current sensor development being performed throughout the Department of Energy complex under various Integrated Programs and Demonstrations. Although a majority of the summarized technologies do not have as a particular end use deployment in a cone penetrometer, those that were selected were deemed applicable through minor modifications. Finally, a summary of commercial vendors by sensor type is included.

\subsection{SENSORS FOR GAS PHASE TANK COMPONENTS}

\subsection{HYDROGEN}

The potential for an explosion due to hydrogen gas exists at atmospheric levels of $\geq 4 \%$. Sensors are required for detecting hydrogen in the percent regime, particularly for regions of gas trapped within the tank waste salt cake matrix. The sensors reviewed here are based either on solid state electronic, optical, or optoelectronic devices.

\subsubsection{SOLID STATE DEVICES}

A potentiometric, solid state electrolyte sensor based on proton transport half cell reactions

$$
\begin{gathered}
\mathrm{H}_{2} \rightarrow 2 \mathrm{H}^{+}+2 e \\
1 / 2 \mathrm{O}_{2}+2 \mathrm{H}^{+}+2 e \rightarrow \mathrm{H}_{2} \mathrm{O}
\end{gathered}
$$

has been reported.C.1 The cell configuration was $\mathrm{Bi}\left(\mathrm{BiF}_{3}\right)\left|\mathrm{Ce}_{0.95} \mathrm{Ca}_{0.05} \mathrm{~F}_{2.95}\right|$ Pt black. The calcium ion doped cerium fluoride was the active sensor solid electrolyte. The Bismuth electrode layer was covered with epoxy to protect the metal from the sample. The response to hydrogen was measured as a change in potential. Response is $5 \mathrm{sec}$ to $1000 \mathrm{~Pa} \mathrm{H}_{2}$ (1\%) (300 $\mathrm{mV}$ response) and $3 \mathrm{~min}$ for $16 \mathrm{~Pa}(0.016 \%)$. Linear slope with $\log \mathrm{P}_{\mathrm{H}_{2}},-116 \mathrm{mV} /$ decade was observed in this range. Sensor was tested at room temperature, in air. Design of the sensor can be compact.

Proton transport was also the mechanism of a compact $\mathrm{Au} I \mathrm{Sb}_{2} \mathrm{O}_{5} \cdot 2 \mathrm{H}_{2} \mathrm{O}$ (antimonic acid) $80 \% /$ PVA $20 \%$ mixture/Pt cell all coated on alumina 
substrate.C.3 As a potentiometric device the response was linear with respect to $\log \mathrm{P}_{\mathrm{H}_{2}}$. It also responded to $\mathrm{CO}$, but not to VOCs. The $\mathrm{H}_{2}$ range was 200 $\mathrm{ppm}$ to $10000 \mathrm{ppm}$ with a slope of $-150 \mathrm{mV} /$ decade. The response to $1000 \mathrm{ppm}$ $\mathrm{H}_{2}$ was $100 \mathrm{mV}$ vs an $\mathrm{Au}$ reference electrode. The device was operated at $30^{\circ} \mathrm{C}$ in air. It required humid air to prevent sensing paste from drying out.

As an amperometric device, the current was linear with hydrogen concentration. The response was $0.2 \mu \mathrm{A}$ at $1000 \mathrm{ppm}$. The current was measured between two Pt electrodes, with EMF supplied by the difference in potential between exposed and embedded Pt electrodes $(100-150 \mathrm{mV})$ in the presence of $\mathrm{H}_{2}$. Response slope was $0.1 \mathrm{nA} / \mathrm{ppm} \mathrm{H}_{2}$. The response time of both devices was $10 \mathrm{~s}$ at $1000 \mathrm{ppm}$.

Another proton transport hydrogen sensor exhibited a wide operating temperature range, $0-200^{\circ} \mathrm{C}$ in air, potentially to $430^{\circ} \mathrm{C}$. C. 4 The cell was $\mathrm{Ti} / \mathrm{TiH}_{\mathrm{x}} \mid \mathrm{Pt}$ or $\mathrm{Pd}$ coated $\mathrm{Zr}\left(\mathrm{HPO}_{4}\right)_{2} \cdot \mathrm{H}_{2} \mathrm{O} / \mathrm{Pt}$ or Pd. Pellicular Zirconia phosphate was the proton conductor, $\mathrm{TiH}_{\mathrm{X}}$ was the solid reference electrode. The device was embedded in ACLAR thermoplastic as moisture barrier. It was operated in $70 \%$ R.H. at room temperature, and exhibited a linear response from 1 to $1000 \mathrm{ppm} \mathrm{H}_{2}$ ( $120 \mathrm{mV} /$ decade). The slope decreased to $35 \mathrm{mV} /$ decade at $200^{\circ} \mathrm{C}$. Long term stability was reported (2 months). A response time of $10 \mathrm{~s}$ at $10 \mathrm{ppm}$ was noted. The device size was not mentioned, although it was referred to as miniature.

A proton transport cell using porous $\mathrm{Pt}\left|\mathrm{BaCe}_{0.9} \mathrm{Nd}_{0.10} \mathrm{O}_{3-\alpha}\right|$ porous $\mathrm{Pt}$, where $\alpha$ is oxygen deficient perovskite-type cell unit was reported.C.7 The two sides of the metal oxide ceramic disk were kept isolated, one side to detect $\mathrm{H}_{2}$, the other in presence of a reference gas, an $\mathrm{Ar}$ and $\mathrm{H}_{2}$ mixture. Variable $\mathrm{H}_{2}$ concentrations were introduced in He. Both sides of the device were exposed to wet gases. It was operated at 200 to $900^{\circ} \mathrm{C}$. EMF was based on a concentration gradient of $\mathrm{H}^{+}$between the electrodes. The cell was EMF linear with $\log \mathrm{P}_{\mathrm{H}_{2}}, 500$ to $200000 \mathrm{ppm}$. The presence of $\mathrm{O}_{2}$ set up second electrode reaction, which drastically decreased the sensitivity of sensor. It was also effected by $\mathrm{H}_{2} \mathrm{O}$.

A solid state proton transport sensor based on a porous $\mathrm{Pt}$ electrode was formed from the cell $\mathrm{Pt}$ paste INASICON ion exchange (acidic, bonded and pressed) | Pt.C.15 The EMF was based on a proton concentration gradient. The reference electrode was held in the presence of $100 \% \mathrm{H}_{2}$, while the active electrode varied from 100 to $100000 \mathrm{ppm}$ in dry nitrogen. A rapid fall off in sensitivity with increasing temperature and water vapor was noted.

A sensor based on the catalytic degradation of oxygenC.2

$$
\begin{aligned}
& \mathrm{O}_{2}+4 e \rightarrow 2 \mathrm{O}^{2-} \\
& 2 \mathrm{O}^{2-} \rightarrow \mathrm{O}_{2}+4 e
\end{aligned}
$$


monitored changes in potential due to the reaction of $\mathrm{O}_{2}$ with $\mathrm{H}_{2}$

$$
\mathrm{O}_{2}+2 \mathrm{H}_{2} \rightarrow \mathrm{H}_{2} \mathrm{O}
$$

The electrochemical cell was $\mathrm{Pt}(+)\left|\mathrm{Y}_{2} \mathrm{O}_{3} / \mathrm{ZrO}_{2}(\mathrm{YSR})\right| \mathrm{Pt}(-) \mid \mathrm{CuO} / \mathrm{ZnO} / \mathrm{Al}_{2} \mathrm{O}_{3}$ electrolyte $\quad \mathrm{H}_{2}$ oxidation catalyst

It was a high temperature sensor, tested over $688-773^{\circ} \mathrm{K}$ (active catalyst temperature). At $703 \mathrm{~K}, 2.5 \mathrm{~min}$ was required to reach a steady state potential $(9 \mathrm{mV})$ at $107 \mathrm{ppm}$ in air. A faster response time was observed at higher temperatures. The linear response range was 0 to $54 \mathrm{ppm}$ at $703^{\circ} \mathrm{K}$, to 142 $\mathrm{ppm}$ at $773^{\circ} \mathrm{K}$. The sensor depended on $\mathrm{O}_{2}$ concentration, but the actual dependence was not reported $\left(\mathrm{O}_{2} \gg>\mathrm{H}_{2}\right)$.

A commercial sensor based on a fuel cell was reported.C.6 In this cell $\mathrm{H}_{2}$ diffused out of a liquid medium across a Teflon membrane into porous $\mathrm{Pt}$ electrode. The fuel cell was supplied by Syprotec. The current was read as voltage across load resistor between the active and counter Pt electrodes. The electrolyte was reported as "acid electrolyte", presumably proprietary. Voltage output ranged from $10 \mu \mathrm{V}$ to $10 \mathrm{mV}$, amplified up to $2 \mathrm{~V}$. It was reported to "also measure gaseous $\mathrm{H}_{2}$ ", 0 to $100 \%$. No interference was noted due to $\mathrm{H}_{2} \mathrm{O}$ or $\mathrm{H}_{2} \mathrm{~S} . \mathrm{O}_{2}$ increased the response time, which in turn was not given.

A thermoelectric sensor was also reported.C.20 Hydrogen concentration was monitored as the change in potential drop across a thermopile made of thermocouples with an element that changes electrical properties due to interaction with $\mathrm{H}_{2}$. Five $\mathrm{Cu}: \mathrm{Pd}$ thermocouples, with an active junction area of $200 \times 200 \mu \mathrm{m}$, were joined in a thermopile. The two ends of junction were at maintained at different $\mathrm{T}$ (constant $\Delta \mathrm{T}$ ) with heat reservoirs. The change in thermoelectric power (defined as thermocouple voltage per degree $\mathrm{K}$ ) with $\mathrm{H}_{2}$ concentration in $\mathrm{N}_{2}$ was measured. The device detected from 88 to 10000 ppm $\mathrm{H}_{2}$, but these were not necessarily the upper and lower limits. It also responded to $\mathrm{O}_{2}(100 \%)$, but at a much smaller level than much lower concentrations of $\mathrm{H}_{2}$; they did not do any mixed gas experiments.

Hydrogen detecting diodes have been under investigation. Several Schottky barrier diodes have been reported. In this type of device, the barrier height of a metal semiconductor Schottky diode junction incorporating a catalytically active metal decreases when the device is exposed to hydrogen. Diode capacitance increases in presence of $\mathrm{H}_{2}$ as $\mathrm{H}$. diffuses through the metal electrode to the semiconductor interface. One such device consisted of a $\mathrm{Au} / \mathrm{Ge}$ ohmic contact ISi-doped GaAs (n-GaAs) IPt schottky contact through masks (mask material not specified).C.12 The device was coated with polyetherimide for chemical resistance. The device operated at 75 to $170{ }^{\circ} \mathrm{C}$, in $\mathrm{N}_{2}$ and dry air, with a response time of $\sim 50 \mathrm{sec}$ to $1200 \mathrm{ppm} \mathrm{H}_{2}$. Response 
was measured as the change in capacitance at $0.1 \mathrm{~V}$ reverse bias. A linear response was observed over 200 to $3000 \mathrm{ppm}$ in air, down to $5 \mathrm{ppm}$ in $\mathrm{N}_{2}$.

A diode based on a $\mathrm{TiO}_{2}, \mathrm{Pd}$-gate $\mathrm{MOS}\left(\mathrm{Si} \backslash \mathrm{TiO}_{2} \backslash \mathrm{Pd}\right)$ was briefly described.C.8 The response, measured as the difference in capacitance gave $\%$ level sensitivity, best observed at 0 gate voltage. It was measured in dry $\mathrm{N}_{2}$ only.

A variation of the Schottky barrier diode was a trench type device.C.9 where a trench was etched in the $\mathrm{SiO}_{2}$ insulator as well as $\mathrm{Pd}$ gate layer. The device geometry was $\mathrm{Pd} / \mathrm{Al}$ separator with hole into $\mathrm{SiO}_{2}$ insulator I $\mathrm{n}-\mathrm{Si} \mid \mathrm{Al}$ substrate. Hydrogen was detected down to $0.1 \mathrm{ppm}$ in Ar. Output could be read as current or voltage drop. Rapid response was reported. No tests in air, nor with temperature were performed.

A diode based on a MIS device (metal/insulator/semiconductor) was reported for measuring $\mathrm{H}_{2}$ outgas from $\mathrm{UO}_{2}$. C.16, C.17 The structure was $\mathrm{PdISiO}_{2} \mid \mathrm{Si}$, with small dimensions $\left(2 \times 2 \times 0.4 \mathrm{~mm}^{3}\right)$. It was operated at $160^{\circ} \mathrm{C}$, and measured 0.1 to $100 \mathrm{ppm} \mathrm{H}_{2}$ with a $30 \mathrm{~s}$ response time in an inert gas atmosphere. The presence of oxygen lead to the formation of water on the device surface, and a decrease in sensitivity.

FET devices have been utilized as $\mathrm{H}_{2}$ sensors.C.11, C.19 A Pd-MISFET device made of a $100 \mathrm{~nm}$ thick $\mathrm{Pd}_{\mathrm{SiN}} \mathrm{SiO}_{\mathrm{y}}$ gate insulator $\mid \mathrm{p}$-Si, was operated with good reproducibility over 5000 hours nonstop operation at $70^{\circ} \mathrm{C} . \mathrm{C} .19$ A linear $\mathrm{V}$ vs $\log \left[\mathrm{H}_{2}\right] \mathrm{ppm}$ with a slope $110 \mathrm{mV} /$ decade was observed. It was speculated that the robustness of device was due to low $\mathrm{H}_{2}$ permeability of insulator, thus reducing $\mathrm{H}$ diffusion and subsequent damage to the semiconductor layer.

A heterostructure FET made of $\mathrm{Al}|\mathrm{p}-\mathrm{Si}| \mathrm{Al}$ mask layer $|\mathrm{ZnO}| \mathrm{Pd}$ operated by $\mathrm{Pd}$ uptake of hydrogen, which altered the current characteristics of device by transferring hydrogen ion to the ZNO layer, increasing conductivity. C.11 The $\mathrm{I}-\mathrm{V}$ characteristics were studied with a simple multimeter at room temperature. The device current was read at a set voltage, with $\Delta \mathrm{I} / \mathrm{I}=50$ at $2 \% \mathrm{H}_{2}$ in $\mathrm{Ar}$ after exposure to air. Ar alone doesn't illicit a response, but no experiments were done in air.

A wide dynamic range hydrogen sensor has been described by Hughes and coworkers. C.22 A $16 \mathrm{~mm}^{2}$ Si chip was fabricated with four types of hydrogen sensors. A chemiresistor consisted of a $\mathrm{Pd} / \mathrm{Ni}$ alloy thin film on a $\mathrm{SiN}_{\mathrm{x}} / \mathrm{SiO}_{2} / \mathrm{Si}$ base with less than 15 atomic $\% \mathrm{Ni}$, and was responsive to hydrogen in air in the concentration range of $0.1 \%$ to $100 \%$. Three MIS capacitors consisting of $\mathrm{Ni} / \mathrm{Pd}, \mathrm{Pd}$, or $\mathrm{Ni}$ on $\mathrm{SiN}_{\mathrm{x}} / \mathrm{SiO}_{2} / \mathrm{Si}$ extended the lower detection limit down to $1 \mathrm{ppm}$ hydrogen in air. The sensor chip was 
UCRL-ID-118561

page 7 of 50

interfaced with an on board microprocessor with a total board area of $8 \mathrm{~cm}$ by $13 \mathrm{~cm}$. The sensor response to hydrogen was rapid $(0.25 \mathrm{sec})$ and reversible.

\subsubsection{OPTOELECTRONICDEVICES}

A photopyroelectronic device has been reported.C.5,C.10 In the photopyroelectric experiment, a potential difference was generated in the direction of poling of beta-polyvinylidene fluoride (PVDF) between two electrodes when a temperature change was induced in the polymer film. A 4 $\mathrm{mW}$ modulated $800 \mathrm{~nm}$ nearIR laser heated the PVDF to set up AC voltages in the poling direction. The laser was hooked to the device via fiber optics. $\mathrm{H}_{2}$ was absorbed onto a Pd electrode, dissociated, and formed $\mathrm{H}^{+}$ions between Pd $\backslash P V D F$, which in turn shifted the pyroelectric coefficient. The active hydrogen sensor was PdIPVDF/Ni-Al. A reference device was NiAl|PVDF|Ni-Al. Output was read via a Lock-in amplifier circuit. The response measured in $\mathrm{N}_{2}$ at $20^{\circ} \mathrm{C}$ was $40-2000 \mathrm{ppm} \mathrm{H}_{2}$. A Langmuirian response was observed

$$
S_{s}=S_{s a t}\left[\frac{K(T) \sqrt{P_{H_{2}}}}{1+K(T) \sqrt{P_{H_{2}}}}\right]
$$

where $\mathrm{K}(\mathrm{T})$ was a temperature constant, $5 \times 10^{-3} \mathrm{~Pa}^{-0.5}$ from curvefit. No air data was presented.

Another optoelectronic device was described as a light addressable Potentiometric Sensor (LAPS).C.21 The principal was photomodulation of the semiconductor space charge in an MIS structure and detection of this modulation in the external circuit as a transient photocurrent. The device used hydrogenated amorphous silicon (a-Si:H). When $\mathrm{Si}: \mathrm{H}$ was illuminated, e:h pairs were separated by an electric field in the space charge region. This modified the net charge in the device, which in turn gave rise to a transient photocurrent, which consequently discharged the unit. When the light went off, the excess charge collected at the semiconductor/insulator interface was thermally emitted and recombined into the semiconductor until electrostatic equilibrium was reached. This produced an opposite sign transient current. Signal was maximized for frequency and gate voltage.

The device was $100 \mathrm{~nm} \mathrm{Cr}$ on glass $|\mathrm{n}+\mathrm{a}-\mathrm{Si}: \mathrm{H}(30 \mathrm{~nm})| \mathrm{a}-\mathrm{Si}: \mathrm{H}(300 \mathrm{~nm})$ la$\mathrm{SiN}_{1.6}: \mathrm{H}(150 \mathrm{~nm})$ I transparent $(15 \mathrm{~nm}) \mathrm{Pd}$ gate electrodes. The device was illuminated at $623.5 \mathrm{~nm}$ with a modulated LED at $4 \mathrm{kHz}$. Gate voltage was

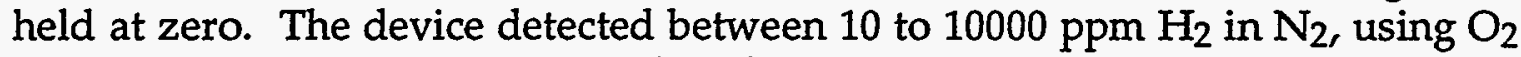
to regenerate device. No study of $\mathrm{H}_{2}$ in air was performed. A linear dependence of $\frac{1}{\Delta V} v s \frac{1}{\sqrt{P_{H_{2}}}}$ was observed where $\Delta V$ was the change in forward bias induced by the transient current changes. 


\subsubsection{OPTICAL DEVICES}

A laser Raman hydrogen gas sensor was reported.C.13 The sensor utilized a multipass Herriot cavity for detection. The experiment was a normal Raman setup, except the laser intensity in field of view of the collection optics was greatly enhanced with multiple passes of $\mathrm{CW}$ laser beam over the same small area in space, essentially integrating the laser power with time. The system utilized a $10 \mathrm{~mW}$ air cooled Ar ion with 30 passes in the Herriot cell. It was a large instrument, and responded to $\mathrm{H}_{2}$ at the $\mathrm{Q}$ branch with a sensitivity of 42 ppm using PMT detection.

A passive optical sensor for detecting $\mathrm{H}_{2}$ at the explosive level was described.C.14 The change in optical reflectivity of a sensor exposed to $\mathrm{H}_{2}$ was interrogated with fiber optics. A $50 \mu \mathrm{m}$ glass core fiber, $38 \mu \mathrm{m}$ clad, was coated with a 10-20 nm thick Pd film deposited by thermal evaporation. The Pd formed a hydride in presence of $\mathrm{H}_{2}$; changes in the reflectivity of the coating were measured using an $860 \mathrm{~nm}$ LED modulated at $10 \mathrm{kHz}$. Reflectivity decreased with increasing hydride formation. At $0.2 \% \mathrm{H}_{2}$ in air, a decrease by $0.1 \%$ was detectable. The unit saturates around $4.8 \%$ with a $\sim 16 \%$ decrease in reflectivity. It can be cycled repeatedly between $\mathrm{H}_{2}$ and air with long term stability.

A colorimetric, solid state sensor based on the catalytic reaction of $\mathrm{H}_{2}$ on a metal was reported.C.18 The catalysis of hydrogen degradation on the metal surface induced a charge transfer to the underlying metal oxide layer, causing a color change which was measured by changes in transmittance. A $500 \mathrm{~nm}$ $\mathrm{WO}_{3}$ film was deposited onto a glass substrate with a $10 \mathrm{~nm} \mathrm{Pd}$ film on top of tungsten layer. Changes in transmittance were observed at $780 \mathrm{~nm}$ (lamp, chopper, monochromator, lockin PMT setup). Dry air and dry air with $\mathrm{H}_{2}$ were used. The sensor darkens at $780 \mathrm{~nm}$ in the presence of $\mathrm{H}_{2}$. Concentration was measured via the response to the maximum absorbance change, giving a linear $\log \left(\mathrm{H}_{2}\right)$ vs $\log$ (time) dependence. The device was sensitive to $100 \mathrm{ppmV}$ in $200 \mathrm{sec}$.

\section{$2.2 \quad$ AMMONIA/AMMONIUM}

The presence of ammonia in the $25 \mathrm{ppm}$ vapor or $0.1 \mathrm{M}$ dissolved ammonium regime needs to be monitored to gauge the contribution of ammonia to toxic gases in both the tank headspace and in vapor pockets in the salt cake matrix. The current standard method of measuring ammonia involves dissolving it in aqueous solution and measuring the resulting $\mathrm{pH}$ using a glass electrode. Sensor technologies reviewed here are based upon electronic and optical devices. 


\subsubsection{ELECTRONIC DEVICES}

An ammonia sensitive resistor has been described.K.3 Changes in resistance induced by oxidation $(\mathrm{HCl})$ or reduction $\left(\mathrm{NH}_{3}\right)$ of a conducting polymer were measured. Polyaniline or polyaniline bis phenol A carbonate were electrochemically polymerized onto a polycarbonate substrate. Resistance was measured using a simple multimeter. Changes were observed from $10^{2}$ to $10^{7}$ $\mathrm{ohm}$ in increasing amounts of ammonia vapor. The response was fully reversible. Concentrations down to $250 \mathrm{ppm}$ were measured, with a time response of 60 seconds. The sensor also responds to $\mathrm{HCl}$ vapor. No report was given on the effect of water vapor or temperature.

A second chemiresistor monitored decreases in resistance in a doped refractory metal oxide semiconductor in the presence of ammonia.K.5 A small tube of alumina was coated with $0.4 \%$ Au doped $\mathrm{WO}_{3}$. The tube was calcined at $700^{\circ} \mathrm{C}$ to form the sensor unit. The signals were measured as $R_{a i r} / R_{a m m o n i a}$. Measurements were performed at $450^{\circ} \mathrm{C}$ in either dry ammonia or dry air. Under these conditions, the resistor could measure down to $5 \mathrm{ppb}$ of ammonia in air. Rapid response and recovery times were noted ( $<3 \mathrm{~min}$ ), but no mention of the effect of moisture was given.

Another metal oxide based chemiresistor was based on p-type titanium doped chromium sesquioxide, $\mathrm{Ti}_{0.2} \mathrm{Cr}_{1.8} \mathrm{O}_{3}$, held at $500^{\circ} \mathrm{C}$ as the sensing medium.K.6 This material was very specific to ammonia, with small response to comparable amounts of $\mathrm{H}_{2}$. It was sensitive to $50 \mathrm{ppm}$ ammonia in dry air, although this was not listed as the detection limit. No calibration curves were given, nor was a report on moisture effect.

An ammonia sensing schottky diode based on Au/Geln-GaAs|n-GaAs epitaxial layer $\mid \mathrm{Pt} /$ porous $\mathrm{Pt}$ electrode was demonstrated.K.4 The change in capacitance across diode was measured. Capacitance was induced through the porous $\mathrm{Pt}$ electrode via ammonia transport to the surface of the semiconductor followed by capacitive coupling of ammonia or reaction products to the surface. Experiments were run at $150^{\circ} \mathrm{C}$ with $0 \mathrm{~V}$ bias. Diode responses as low as $8 \mathrm{ppm}$ ammonia in 50:50 $\mathrm{O}_{2}: \mathrm{N}_{2}$ dry atmosphere were reported. The response time was on the order of several minutes. Major interference by $\mathrm{H}_{2}$, which gives an increase in capacitance approximately twice that of ammonia (each at 8ppm level) were observed.

\subsubsection{OPTICAL DEVICES}

A direct line of sight nearIR laser gas cell for ammonia sensing was demonstrated. $\mathrm{K} .1$ The absorbance of an $\mathrm{NH}_{3}$ vibrational overtone $\left(2 \sqrt{1}_{1}\right.$ band, $6400 \mathrm{~cm}^{-1}$ ) was detected using a photodiode. The diode laser wavelength was $1.5 \mu \mathrm{m}$ at unspecified power output. Output was modulated and detected via 
lockin amplifier. Fast response time $(1 \mathrm{sec})$, with a minimum detection level of $2.2 \times 10^{-2}$ Torr $\mathrm{m}$ (29 ppm) at atmospheric pressure was reported. The pathlength utilized in this setup was $1 \mathrm{~m}$, with greater sensitivity envisioned at longer pathlengths. No discernible interference from water of $\mathrm{CO}_{2}$ was noted. The system has been tested in an "industrial environment". No mention of a fiber optic interface, but it should be trivial to modify the system for a remote fiber optic configuration.

A novel fiber optic ammonia sensor based on an indicator solution was used to detect ammonia above an aqueous ammonium solution. K.2 Changes in the fluorescence from a pH indicator dye excited and collected by fiber optics were used as the active sensing mechanism. The system utilized an unsupported solution in a capillary with an air gap between the fibers (side by side configuration) and the indicator solution, then an additional air gap (distance from solution to bottom of capillary) between the indicator and the sample. The aim was to optically mimic a miniature glass $\mathrm{pH}$ sensor based on air gap designs. The probe was sensitive to $5 \times 10^{-7} \mathrm{M}$ dissolved ammonia in aqueous solution with a 3 to 10 minute response time. The indicator used was carboxyfluorescein, excited at $490 \mathrm{~nm}$. Emission was observed at $540 \mathrm{~nm}$. While not of use itself in the tank environment, a similar sensor with a teflon membrane for isolating the indicator solution from the environment might be feasible.

\subsection{VOLATILE ORGANIC COMPOUNDS (VOC)}

The contribution of VOCs to the toxic vapors in the headspace of the tanks needs to be determined. In addition, the presence of VOCs may be used to indicate the presence of potentially unstable organonitrate compounds. The sensors reviewed are based on solid state electronic and optical devices.

\subsubsection{ELECTRONIC DEVICES}

An array of eight sensors, separated into 4 heated pairs, was fabricated on a single chip. ${ }^{N .1}$ The VOC microsensors were metal and metal oxide gate electrodes, each gate made of a different material with eight differing responses to types of VOC. The signal from each sensor was read, and the data analyzed using an unspecified neural network. The gate pairs were made of $\mathrm{SnO}_{2}, \mathrm{SnO}_{2} / \mathrm{Pd} ; \mathrm{WO}_{3} / \mathrm{SnO}_{2}, \mathrm{Pd} / \mathrm{WO}_{3} / \mathrm{SnO}_{2} ; \mathrm{ZnO} / \mathrm{SnO}_{2}$, $\mathrm{Pd} / \mathrm{ZnO} / \mathrm{SnO}_{2} ; \mathrm{TiO}_{2} / \mathrm{SnO}_{2} ; \mathrm{Pd} / \mathrm{TiO}_{2} / \mathrm{SnO}_{2}$ on $\mathrm{p}-\mathrm{Si} / \mathrm{n}-\mathrm{Si} / \mathrm{n}^{+}-\mathrm{Si} / \mathrm{Al}$. The source electrode was $\mathrm{Al} / \mathrm{Cr}$ attatched to the $\mathrm{p}-\mathrm{Si}$. The sensor arrays were sensitive to $50 \mathrm{ppm}$ methanol and $60 \mathrm{ppm}$ acetone. The response time was under 1 minute. The neural network processor demonstrated promise in the identification of components and quantities in mixtures of acetone and methanol. Such a solid state device, based on microchip technology, could prove promising for detecting a large array of VOCs. 
A chemiresistor based on changes in the resistance (DC) of a refractory metal oxide semiconductor in the presence of VOC was reported. N.3 Small size ceramic pellets were the active sensor element. The active sensors were a series of bismuth ferrites, $\mathrm{Bi}_{2} \mathrm{Fe}_{4} \mathrm{O}_{9}, \mathrm{Bi}_{4} \mathrm{Fe}_{2} \mathrm{O}_{9}$, and $\mathrm{BiFeO}_{3}$. Sensor responses to VOCs in air were measured over the temperature range 200 to $450^{\circ} \mathrm{C}$. Signal was measured as $R_{\text {gas }} / R_{\text {air }}$. The devices were sensitive down to 500 $\mathrm{ppm}$ of hexanes in air. They were also responsive to ethanol, acetone, and natural gas. There was no interference by moisture.

A MOSFET with 6 detectors made of different gate materials with differing responses to vapors has been demonstrated.N.4 The gates were made of Pt, $\mathrm{Pd}$, and Ir. The MOSFET was run in constant current mode. Exposure to gas changed the threshold voltage of device, which was detected. Signals were processed via a three layer neural network to recognize the concentrations of five components $\left(\mathrm{H}_{2}, \mathrm{NH}_{3}\right.$, ethylene, ethanol, and acetone). The unit was sensitive down to $5 \mathrm{ppm}$ of $\mathrm{H}_{2}, \mathrm{NH}_{3}$, and acetone in the presence of other gases, with rapid, reversible response. The device operated at 100 to $200^{\circ} \mathrm{C}$.

Commercially available Surface Acoustic Wave (SAW) devices, which were basically piezoelectric microbalances, were coated with various polymers for the selective uptake of organic vapors. N.5 An array of sensors were used, and signals were analyzed via PLS regression to identify and quantify components in mixtures of gases. The SAW devices were operated at $30 \pm 0.01^{\circ} \mathrm{C}$ (device is extremely temperature sensitive). Dry gas mixtures were used, with no mention of the effect of moisture. Sensitivity down to $4 \mathrm{ppm}$ for toluene in the presence of other organic vapors was demonstrated.

\subsubsection{OPTICAL DEVICES}

A colorimetric fiber optic sensor for direct deployment in a cone penetrometer has been developed and field tested.N.7 The sensor involved monitoring the rate of color formation of the reaction between a reagent and the analyte via changes in light transmission at the product absorbance maximum. The formation of the red product that resulted from the irreversible Fujiwara reaction between basic pyridine and TCE was monitored via a fiber optic flow sensor consisting of an LED, a photodiode, and a permeable teflon membrane flow tube active sensor. The reagent was sensitive to TCE from $5 \mathrm{ppb}$ up to hundreds of $\mathrm{ppm}$ in air. The sensor utilized a flow system to deliver fresh reagent on demand. The components of this sensor were incorporated and field tested in a $33.75 \mathrm{~mm}$ i.d. cone penetrometer utilizing a removable tip for exposure of the sensor to vapors in the vadose zone of contaminated soil. The sensor was pushed to $41 \mathrm{~m}$ in 50 minutes and recorded levels of TCE under static conditions or active pumping of TCE from the soil. The reagent was reported to be stable over 
several months of storage. With the choice of appropriate liquid reagents, sensing of a large number of VOCs should be feasible.

VOC monitoring via light loss in a planar waveguide made of a glass support coated with methacrylate or thiolene photopolymer was reported.N.2 The waveguide was coupled to a Ne lamp and detector via fiber optics, with transmission losses from exposure to VOC being monitored. The device was tested with high vapor concentrations in moist nitrogen (10000 ppm). It only responded to acetone and chloroform. The presumable sensing mechanism was reported as swelling of the polymer by uptake of VOC. The device gave a linear double log intensity versus concentration plots from 10000 to 500000 ppm.

A VOC sensing thermoluminescence device (TLD) was reported.N.6 Luminescence was observed upon heating VOC impregnated aluminum oxide $\left(\gamma-\mathrm{Al}_{2} \mathrm{O}_{3}\right)$. The luminescence maxima (PL) and thermal intensity profiles (TL) were substance dependent, with the total luminescence yield dependent on the concentration of absorbed vapor. Luminescence was due to chemiluminescence during catalytic oxidation of organic compounds on the surface. The experimental setup involves alumina powder in a platinum boat which is resistively heated to $300^{\circ} \mathrm{C}$. Luminescence was observed by a CCD camera. Dry vapors in air were used. The alumina was pretreated by annealing at $700^{\circ} \mathrm{C}$ for 10 minutes before exposure to organics acetone, butyric acid, and butanol. Detection ranges of $50 \mathrm{ppb}$ to $1000 \mathrm{ppm}$ were observed. The effect of water was not investigated.

\subsection{MERCURY}

The contribution of mercury vapors to the toxic vapors in the tank headspace needs to be determined. The current techniques for mercury monitoring include photoacoustic spectroscopy, mass spectroscopy, and atomic absorption spectroscopy. The reviewed technologies are based on solid state electronic sensing.

A SAW device, quartz microbalance based on absorption of $\mathrm{Hg}$ vapor by a gold coating has been reported.P.2 The frequency of the piezoelectric quartz resonator was dependent on the mass loading of the surface coating. The change in resonator frequency was linearly dependent on the mass of the surface coating. Mercury vapor detection was linear over a range of $2 \times 10^{-5}$ to $4 \times 10^{-2} \mathrm{~g} / \mathrm{m}^{3}$ (1.5 pptV to $\left.2.9 \mathrm{ppbV}\right)$, with a lower limit of $6 \times 10^{-6} \mathrm{~g} / \mathrm{m}^{3}(0.45 \mathrm{ppt})$. One limitation of the sensor was the need to heat the gold electrode to $150^{\circ} \mathrm{C}$ to clean the surface of mercury. This paper addressed that issue using a built in resistive heater. The mercury desorption time is 30 minutes. No report was given on other environmental effects, nor interferents. 
A solid state, potentiometric sensor for the determination of dissolved mercury was reported.P.1 A heterogeneous plastic membrane mixed with polytungstoantimonate encapsulated a reference solution of $0.5 \mathrm{M} \mathrm{HgCl}$ over a metal electrode. The potential difference across the membrane between the sample and a reference solution was measured. The sensor responded to dissolved mercury with a linear potential versus $\log \left[\mathrm{Hg}^{2+}\right]$ dependence over the range of 0.1 to $10^{-4} \mathrm{M}$ in aqueous solution. The sensor was strongly effected by $\mathrm{pH}$ and monocations such as $\mathrm{Na}^{+}$and $\mathrm{K}^{+}$. Limited stability was noted, approximately eight minutes during the sensing of $\mathrm{Hg}$.

\subsection{SENSORS FOR LIQUID AND SOLID PHASE TANK COMPONENTS}

\subsection{FERROCYANIDE ION}

The currently planned technique for the determination of ferrocyanide in the tank waste matrix is Raman spectroscopy, which has been shown to be sensitive down to approximately $0.01 \%$ by dry weight in simulants. A search of the literature revealed only one reference to a ferrocyanide chemical sensor which might serve as a complement to the Raman technique. The sensor was a polymer coated rotating disk electrode for solutions.A.1 The study was aimed more at demonstrating the utility of the polymer bound electrode gate molecule $\mathrm{Ru}\left(\mathrm{Ru}\right.$ (bipy)2(PVI) $\left.{ }_{\mathrm{X}} \mathrm{Cl}\right) \mathrm{Cl}$ than at producing a ferrocyanide specific electrode. The oxidation of $\mathrm{Fe}(\mathrm{II})$ to $\mathrm{Fe}(\mathrm{III})$ was mediated by the polymer bound $\mathrm{Ru}(\mathrm{II})$ to $\mathrm{Ru}$ (III) couple. The limiting current of the cell reaction $\mathrm{Ru}(\mathrm{II})--->\mathrm{Ru}(\mathrm{III})+\mathrm{Fe}(\mathrm{II})-->\mathrm{Ru}$ (II) + Fe(III) was measured. The polymer was coated on a glassy carbon electrode. Cyclic voltammetry was performed using a potentiostat. At $\mathrm{pH} 2 \& 6$, the electrode can measure down to $5 \times 10^{-6} \mathrm{M}$ ferrocyanide, with a linear $\log (\mathrm{i})$ (limiting current) vs $\log [\mathrm{Fe}(\mathrm{II})]$ dependence. The sensor also responds to $\mathrm{FeSO}_{4}$. The electrode is not specific, and other species which can be oxidized at the $\mathrm{Ru}(\mathrm{II}) / \mathrm{Ru}(\mathrm{III})$ potential will respond as well.

\subsection{CYANIDE ION}

In the absence of a ferrocyanide specific chemical sensor, the possible presence of ferrocyanide may be inferred indirectly utilizing a cyanide $\left(\mathrm{CN}^{-}\right)$specific chemical sensor. The sensors reviewed are optical sensors.

A colorimetric, irreversible sensor based on the chemical reaction of $\mathrm{HCN}$ with compounds impregnated in a permeable polymer resin was reported.L.1 Amberlite XAD-7 resin beads were impregnated with chloramine- $\mathrm{T}$, 4picoline, and barbituric acid. The hydrogen cyanide gas was oxidized by reaction with chloramine to give cyanogen chloride, $\mathrm{CN}^{+} \mathrm{Cl}^{-}$. The cyanogen then reacted with 4-picoline to give glutaconaldehyde, a conjugated dialdehyde, in the presence of atmospheric moisture. The dialdehyde 
UCRL-ID-118561

page 14 of 50

coupled to the barbituric acid via reaction with the methylene hydrogens to give a colored complex, $\lambda_{\max }=540 \mathrm{~nm}$. The change in absorbance of the resin was monitored by the change in reflectance at $540 \mathrm{~nm}$ as observed by a fiber optic probe. Light was modulated and signal analyzed via lock-in amplifier. The sensor was sensitive to $1 \mathrm{ppmV} \mathrm{HCN}$ in air in under 1 minute. The solid state reagent is not reusable, however a solution based system may be employed in the cone penetrometer in the same fashion as the TCE vapor sensor designed by Milanovich et al (reference N.7). The sensing scheme presented should also be capable of detecting $\mathrm{CN}^{-}$in solution, as the reagent responds to $\mathrm{CN}^{-}$-specifically.

A second paper utilizing the detection scheme above details the design of a portable detection system.L.2 In this system, the tungsten lamp was replaced by two LEDs, one at $560 \mathrm{~nm}$ to monitor changes in absorption due to the reaction of $\mathrm{CN}^{-}$, the other at $635 \mathrm{~nm}$ as a reference channel. The rate of change of absorbance was used to determine $\mathrm{CN}^{-}$concentration, not the absolute absorbance, to nullify losses in absolute absorbance due to the aging of the reagent.

\subsection{NITRATE ION}

Nitrate ion is easily detected by Raman spectroscopy. It is the major component of the solid tank wastes. Chemical sensors for nitrate would be a complementary technique used to measure local concentrations of nitrate for the determination of nitrate to nitrite ratios. The sensors reviewed here are based on nitrate specific electrodes and optical techniques.

\subsubsection{ELECTRODE DEVICES}

Several nitrate selective coated electrodes have been reported. B.1, B.2, B.5, B.6 The first device was based on a polypyrrole (PPY) coating on a Pt electrode for solution measurements. ${ }^{B} .1$ The electrode measured $\mathrm{NO}_{3}{ }^{-}$via potential changes from 0.1 to $1 \times 10^{-5} \mathrm{M}$ in water. Increasing ionic strength caused a decrease in sensitivity at the lower concentration. A linear $E$ vs $\log \left[\mathrm{NO}_{3}\right]$ was observed above $10^{-3} \mathrm{M}$, with curvature evidenced below. The PPY electrode was grown in $\mathrm{HNO}_{3}$, so $\mathrm{NO}_{3}^{-}$was present in the polymer to activate the electrode. At the operating potential, $0.6 \mathrm{~V}$, PPY was in a cationic state, and the potential was due to flow of $\mathrm{NO}_{3}{ }^{-}$from the polymer to the solution, dependent on the concentration in solution. It also responded to other ions. The cell required a counter $(\mathrm{Pt})$ and reference $(\mathrm{Ag} \mid \mathrm{AgCl})$ electrode.

A second device monitored current flow due to the direct reduction of nitrate at a freshly deposited copper electrode in a capillary tube.B.2 A sample of nitrate solution was taken up via capillary action. The test solution contained nitrate and sulfuric acid/copper sulfate. Copper was reduced onto a substrate 
at $-0.6 \mathrm{~V}$ vs SCE; the potential was then ramped to $-0.9 \mathrm{~V}$, where nitrate was reduced on the freshly plated copper. Response, recorded over the range $1 \times 10^{-}$ 5 to $1 \times 10^{-2} \mathrm{M}$, exhibited a linear response of $\mathrm{I}$ vs $\left[\mathrm{NO}_{3}\right]$ between $1 \times 10^{-5}$ to $2.5 \times 10^{-}$ ${ }^{3} \mathrm{M}$, then levels off. Relatively little interference from other ions at the potential used was observed.

A third device was based on a polymer coating with nitrate binding groups covalently bound. B.5,B.6 The polymer was used as a membrane in commercial liquid filled ( $0.1 \mathrm{M} \mathrm{NaNO}_{3}$ ) electrode body. The cell potential vs $\mathrm{Ag} / \mathrm{AgCl}$ was read. In the first paper, an SBS elastomer with quaternary ammonium salts bound through pendant allyl groups as a nitrate sequestering agent was utilized. Good sensitivity (to $10^{-5} \mathrm{M}$ ) and lifetime were observed, but poor selectivity. In the second paper, polyacrylonotrile butadiene plastic is polymer phase, which resulted in good mechanical properties and better selectivity, although $\mathrm{I}^{-}, \mathrm{SCN}^{-}, \mathrm{ClO}_{4}^{-}$, and $\mathrm{MnO}_{4}{ }^{2-}$ were still potential interferents.

\subsubsection{OPTICAL DEVICES}

A colorimetric polymer coating that monitored the flow of nitrate into the membrane via proton transfer from a polymer bound chromophore was reported.B.3 A PVC membrane was doped with both a nitrate ionophore, nickel(II) phenanthroline (NiPhen), and a proton selective chromophore, bromocresol purple. The theory was that the NiPhen complex would selectively bind nitrate from aqueous solution. To balance the charge of negative nitrate ions, protons would flow into membrane as well and bind to the indicator chromophore according to

$$
\mathrm{NO}_{3}^{-}{ }_{\mathrm{aq}}+\mathrm{H}^{+}{ }_{\mathrm{aq}}+\mathrm{Io}^{+}{ }_{\mathrm{mem}}+\mathrm{Ind}^{-}{ }_{\mathrm{mem}} \leftrightarrow \mathrm{Io}^{+} \mathrm{NO}_{3}{ }^{-}{ }_{\mathrm{mem}}+\mathrm{Ind}^{-} \mathrm{H}^{+}{ }_{\mathrm{mem}}
$$

The $\mathrm{pH}$ indicator changed color as protons bind reversibly to it. Signal was measured as absorbance changes at $612 \mathrm{~nm}$. Demonstrated at $\mathrm{pH} 6.9$, the sensor was sensitive to $10^{-5} \mathrm{M}$ nitrate, with a linear $\mathrm{A}$ vs $\log \left[\mathrm{NO}_{3}\right]$ observed at greater than $3 \times 10^{-4} \mathrm{M}$. This scheme could possibly work at other $\mathrm{pH}$ ranges if other indicator dyes were used. Response was noted for other anions as well, though smaller than that observed with nitrate.

A similar sensor measured signal as a change in reflectance.B.4 Using the same ionophore as above, a range of proton indicator dyes for $\mathrm{pH} 7,5.8$, and 3.0 was investigated. Limited stability of sensor (10\% decrease in absorbance of sensor under continuous operation, 1 to 14 days) was noted. The sensor response time was $90 \mathrm{sec}$ new, $9 \mathrm{~min}$ after two weeks. Problems with dye leaching were also reported. 
UCRL-ID-118561

page 16 of 50

\section{$3.4 \quad$ NITRITE ION}

Chemical sensors to complement the Raman technique for the measurement of nitrite ion have been reviewed. These sensors were based on coated electrodes.

A glassy carbon electrode was coated with an electrocatalytic polymer for the electrochemical reduction of nitrite to nitrous oxide. 0.1 The concentration of nitrite was observed via changes in current at $120 \mathrm{mV}$ applied potential vs $\mathrm{SCE}$. The reduction of nitrite was mediated at the osmium centers of polymeric $\left[\mathrm{Os}(\text { bipy })_{2}(\mathrm{PVP})_{10} \mathrm{Cl}\right] \mathrm{Cl}$. A linear response was observed in the range of $5 \times 10^{-6}(225 \mathrm{ppb})$ to $1 \times 10^{-2}(450 \mathrm{ppm}) \mathrm{M}$. The sensor exhibited good reproducibility over time, and no interference due to chloride, nitrate, sulfate, phosphate, carbonate, or dissolved oxygen was observed. The polymer degrades over $46 \mathrm{~h}$ in acid. Measurements were made at $\mathrm{pH}$ 1.0.

A coated glassy carbon electrode utilizing an inorganic film of copperheptacyanonitrosylferrate (CuHNF) for both the oxidation and reduction of nitrite has been reported. 0.2 The best results were obtained via amperometric reduction of nitrite at $-0.55 \mathrm{~V}$ vs $\mathrm{SCE}$ at $\mathrm{pH} 5.0$. A linear current versus concentration dependence over the range $1 \times 10^{-6}(45 \mathrm{ppb})$ to $1 \times 10^{-3}(45 \mathrm{ppm}) \mathrm{M}$ was observed. Common anions did not interfere, but peroxide and dissolved $\mathrm{O}_{2}$ interference was noted due to reduction at the operating potential.

A polymer coated modified $\mathrm{Pt}$ electrode detected nitrite via electro-oxidation to nitrate. 0.3 The platinum electrode was chemically modified with iodine, then coated with quaterinized poly(4-vinylpyridine), qPVP. The electrode assembly consisted of the modified $\mathrm{Pt}$ electrode, an unmodified $\mathrm{Pt}$ counter electrode, and an $\mathrm{Ag} / \mathrm{AgCl}$ electrode bounded in one plane by epoxy. A small plug containing $0.1 \mathrm{ml}$ dihydrogenphosphate buffer at $\mathrm{pH} 4.6$ with a P-1025 anion exchange membrane was attatched. The electrode contacted the sample through this electrolyte solution. Test solutions were at $\mathrm{pH}$ 3-8. The electrode was operated at $0.7 \mathrm{~V}$ vs $\mathrm{Ag} / \mathrm{AgCl}$. Steady state currents were obtained in under 5 minutes. The linear operating range was $180 \mathrm{ppb}$ to 180 ppm. Interfering species were those that are oxidized at $0.7 \mathrm{~V}$, such as thiocyanate, bromide, and iodide. No interference from either nitrate or oxygen was observed.

\subsection{IONIC SPECIES}

Sensors for the detection of metal ions that cannot be directly observed by Raman spectroscopy are reviewed here. Metal ions of interest are heavy metals, aluminum, and iron (as an indicator of ferrocyanide). Also sensors for the analysis of anions other than nitrate, nitrite, and cyanide are covered. The devices reviewed are both electronic and optical in nature. 
UCRL-ID-118561

page 17 of 50

\subsubsection{ELECTRONIC DEVICES}

A field effect transistor based on two $n$ type diffusion areas as source and drain embedded in a p-type Si substrate has been reported for the detection of metal cations.D.6 The conductance channel between the source and drain was a function of the perpendicular electric field to the gate oxide surface. The potential of the gate changed due to interactions of an ion selective membrane coated on the gate with ions in solution, which in turn caused a membrane potential. Calix[4]arenes of varying chemical substituents and consequently varying pore diameter to accommodate specific ions were used as ion specific sequestering agents. Calixarenes were bound in PVC, which in turn was cast onto a polyHEMA (hydroxyethyl methacrylate) hydrogel chemically bound to the gate oxide layer. The gate response to ions in solution was monitored via the source potential in a constant source/drain current configuration at a fixed drain potential. Ions investigated were $\mathrm{Ag}^{+}$, $\mathrm{Cu}^{2+}, \mathrm{Cd}^{2+}$, and $\mathrm{Pb}^{2+}$. Good selectivity was demonstrated for different calixarenes, with sensitivities down to $10^{-6} \mathrm{M}$. All measurements were performed at $\mathrm{pH} 4$. No mention of time response was given.

A potentiometric anion sensor based on a conducting polymer was reported.D.4 The polymer was doped with the analyte anion at the time of electrochemical polymerization onto a glassy carbon electrode. Changes in potential vs concentration against a SCE were monitored. Anions studied were nitrate, chloride, bromide, perchlorate. All exhibited a linear potential vs $\log [\mathrm{X}]$ dependence between 0.1 to $10^{-4} \mathrm{M}$, with detection limits down to $10^{-}$ $5 \mathrm{M}$. The operating range was $\mathrm{pH} 3-8$. Cross selectivity was noted, particularly between ions of similar charge and ionic radius. Electrodes also responded to ions in nonaqueous media, such as ethanol and acetonitrile.

\subsubsection{OPTICAL DEVICES}

A variation of a Raman probe has been reported to detect ions indirectly via interaction with surface enhanced Raman spectroscopy (SERS) active probe molecules. D.1 The Raman spectrum of a probe molecule changed with increasing metal ion concentration. Peaks which did not undergo alterations served as an internal reference. The tip of an optical fiber was roughened with coarse grade alumina. 20 to $40 \mathrm{~nm}$ of $\mathrm{Ag}$ was vacuum deposited on the tip. This produced a SERS active metal coating. The SERS probe indicator dyes were modified with cystamine, which provided a binding site of the indicator to the $\mathrm{Ag}$ surface, and also protected the Ag surface from deterioration. The indicator Eriochrome Black T (EBT) was used for $\mathrm{Cu}^{2+}$, $\mathrm{Pb}^{2+}, \mathrm{Mg}^{2+}, \mathrm{Ca}^{2+}, \mathrm{Sr}^{2+}$, and $\mathrm{Ba}^{2+}$. Copper was observed by the $1403 \mathrm{~cm}^{-1}$ peak of a EBT-C $\mathrm{Cu}^{2+}$ complex, and showed linear log(signal - reference peak) vs $\mathrm{pCu}$ down to $85 \mathrm{ppb}$ at $\mathrm{pH} 9$. Lead was observe down to $270 \mathrm{ppb}$ with $3 \mathrm{sec}$ 
integration time. Each metal ion gave unique Raman peaks that could be used as a probe. The dye 4-(2-pyridylazo-resorcinol) was bound to the $\mathrm{Ag}$ surface via disulfide derivitization. It was used to detect $\mathrm{Pb}$ and $\mathrm{Fe}(\mathrm{III})$. The technique was also used to successfully probe changes in $\mathrm{pH}$ indicator dyes. In all cases, laser excitation was used, with $<20 \mathrm{~mW}$ power and $<30 \mathrm{~s}$ integration time.

A SERS sensor for the direct observation of anions was demonstrated.D.3 $\mathrm{Ag}$ islands were doped into PVA film by counterdiffusion of $\mathrm{Ag}^{+}$and $\mathrm{BH}_{4}^{-}$. The films were dipped into the solution to be analyzed for two hours, then removed, washed with water, then dried. SERS spectra were subsequently recorded. Anions that exhibited responses were sulfate and carbonate. Detection limits were not reported, though the same technique measured adenine down to $10^{-9} \mathrm{M}$, with linear intensity vs concentration dependence.

A multipurpose ion selective device based on a sol gel glass sensor has been reported.D.2 Species selective chromophores were incorporated into the sol gel glass during the gelation process. Analytes diffused into the pore network of the xerogel and interacted with the indicator dyes. Color changes were observed via absorbance or reflectance measurements. The response time from seconds to tens of minutes, with excellent sensitivity for $\mathrm{Fe}(\mathrm{II}), \mathrm{Ni}(\mathrm{II})$, $\mathrm{Cu}(\mathrm{II})\left(10^{-6}\right.$ to $\left.10^{-7} \mathrm{M}\right)$, and less sensitive for $\mathrm{Al}(\mathrm{III})$, carbonate, sulfate, lead, and cobalt. $\mathrm{pH}$ from 8.2 to 10.4 was observed in $1 \mathrm{sec}$ with $\mathrm{pH}$ indicator dyes. There is great potential for these types of sensors, as the glass is optically transparent, chemically inert, photostable, and can be prepared to be radiation hardened using the appropriate gelation conditions.

An iron(II) specific sol gel sensor has been demonstrated.D.5 Iron(II) ion penetrated into the sol gel and interacted with trapped colorimetric chelating agent. The sol gel was doped with phenanthroline. Iron was measured in $\mathrm{pH}$ 4 solutions. Changes were monitored at the $512 \mathrm{~nm}$ absorbance peak relative to the $800 \mathrm{~nm}$ baseline. Linear plots of absorbance vs $\log [\mathrm{Fe}]$ were observed down to $10^{-9} \mathrm{M}$ by direct observation in solution. The sol gel could also act as a sequestering agent for analyte, so lower levels of $\mathrm{Fe}$ (II) could be detected if longer standing times were allowed. No report was given on $\mathrm{pH}$ effect or reversibility.

\section{$3.6 \quad \mathrm{pH}$}

The $\mathrm{pH}$ of tank matrices needs to be determined. This is driven by concerns for the tank corrosion at $9.5 \leq \mathrm{pH} \leq 12$. The standard method for determining $\mathrm{pH}$ is glass $\mathrm{pH}$ electrodes. The sensors reviewed here are based on optical techniques. 
A fiber optic $\mathrm{pH}$ sensor designed for contact with in vivo fluids has been described.H.1 Changes in absorbance at $625 \mathrm{~nm}$ were monitored. The dye used was a modified azo $\mathrm{pH}$ indicator with a range of $\mathrm{pH} 7-9$. The change in absorbance was given as a decrease in reflectance as $\mathrm{pH}$ increased. The system utilized a $630 \mathrm{~nm}$ LED source. A linear range of signal vs ratio was observed over the range $\mathrm{pH} 6.5$ to 8 , with a resolution of $\pm 0.01 \mathrm{pH}$ units. The azo dye was chemically bound to common cellophane, which was then sealed in a capillary with holes cut in the sides for solution contact. The signal was stable over 40 days in solution. The authors mention the effect of gamma radiation, which caused a $21 \%$ decrease in the initial $618 \mathrm{~nm}$ absorption after $2.5 \mathrm{mRad}$ exposure. Other dyes may be used to extend the $\mathrm{pH}$ range.

A second fiber optic sensor utilized a pH indicator in porous sol gel glass. H.2 The interaction of the dye with protons from solution is observed as changes in emission. The dye utilized was fluorescein isothiocyanate, which was incorporated into the sol gel during gelation. A chemical linker was used to bind the dye to the glass to minimize leaching. The sol gel was cast on microscope slides, which were coupled to a 6 around 1 fiber optic. They report that response was good, but no data was presented.

The determination of $\mathrm{pH}$ via absorbance changes due to proton interaction with sol gel entrapped indicator dye has been described.H.3 The authors utilized glass sensors that cover the entire $\mathrm{pH}$ range based on different indicator dyes. Sensor response was on the order of seconds to minutes. Leaching studies showed that dyes leach out of the glass under acidic conditions over hundreds of hours. The transmission from one fiber through the glass and into another fiber was monitored. Good reproducibility was observed.

Another absorbance based sensor utilized a $\mathrm{pH}$ indicator immobilized in a polymer film.H.4 The authors designed a portable $\mathrm{pH}$ monitoring unit based on LEDs and fiber optics. Two wavelengths were monitored, one on each side of the $\mathrm{pH}$ induced isosbestic point of the indicator dye congo red. The signal from the indicator film was read as the ratio of the two wavelengths reflected from the film. The diodes were modulated out of phase and both a reference and signal photodiode detector were used to read the light intensity. The dye was cast in a cellulose acetate film and mounted on a GRIN lens, which was coupled to two fiber optics, one for illumination and one for collection. $\mathrm{pH}$ was be determined between 0.88 and 4.2 within $\pm 0.1 \mathrm{pH}$ units. The authors stated that additional colorimetric sensors, including other $\mathrm{pH}$ ranges and heavy metals, were under development.

\subsection{RADIATION SENSORS}

The purpose of radiation sensors for inclusion in the cone penetrometer is severalfold. Sensors are required for measuring the total amount of radiation 
UCRL-ID-118561

page 20 of 50

or radiation flux to which the penetrometer is exposed to evaluate the amount of damage and consequent signal degradation that may occur to optical and electrical components within the penetrometer. In addition, radionuclides for which there are neither Raman nor other types of specific sensors can be characterized by their natural beta $\left(\beta^{-}\right)$and gamma $(\gamma)$ ray spectral features. The pertinent spectral features of ${ }^{137} \mathrm{Cs},{ }^{90} \mathrm{Sr},{ }^{99} \mathrm{Tc},{ }^{129} \mathrm{I}$, $239,240 \mathrm{Pu}$, and $235,238 \mathrm{U}$ are shown in the radioactive decay schemes summarized in Appendix A.M.1 Alpha particles are not considered due to their low penetrating power and the necessary large area detectors for alpha detection. A variety of electrooptic and optic devices have been reviewed for these purposes.

\subsection{TOTAL RADIATION EXPOSURE}

Two types of exposure sensors have been reviewed. Passive sensors respond to total dose accumulated over time, and need to be reset after reading. Active sensors respond to radiation flux, and return an immediate response to radiation. The radiation fluxes in the tank are estimated to be 75 to 900 $\mathrm{R} / \mathrm{hr}$ in the headspace, and up to $10.5 \times 10^{3} \mathrm{R} / \mathrm{hr}$ in the waste matrix.

\subsubsection{PASSIVE DEVICES}

A detector system for particle tracking based on photochromic solids has been described.F.1, F.2 This system is included in this review as the technique is directly applicable to determining total radiation exposures. Radiation induced color changes were utilized to track particles traveling through the photochromic solid. In this case it was the oxidation of $\mathrm{Fe}$ (III) to $\mathrm{Fe}$ (IV) in $0.1 \%$ doped $\mathrm{SrTiO}_{3}$. The effect was transient unless an electric field was applied to prevent recombination of $\mathrm{e}^{-}$and $\mathrm{Fe}$ (IV) centers. Black $\mathrm{Fe}(\mathrm{IV})$ doped strontium titanate was reduced to pale yellow Fe(III) under high temp $\left(900^{\circ} \mathrm{C}\right)$ at low pressure. Radiation induced a return of the black color, but it was immediately reversible unless recombination was prevented. The size of the crystal was $2 \mathrm{~cm}$ radius by $2 \mathrm{~mm}$ thick, with a $1000 \mathrm{~V}$ potential across the crystal. The yellow color can be regenerated(device reset) by reversing the potential.

A fiber optic, optically addressed thermal luminescence dosimeter has been reported.G.1 In this device crystal irradiation resulted in a population of trapped electrons. Pumping the crystal in the nearIR resulted in the release of these electrons with a concomitant release of visible luminescence. The phosphor utilized was $\mathrm{SrS}: \mathrm{Ce}, \mathrm{Sm}$, which was a wide band gap semiconductor. Under ionizing radiation, charge transfer was induced between $\mathrm{Ce}(\mathrm{III})$ and Sm(III), giving $\mathrm{Ce}$ (IV) and $\mathrm{Sm}$ (II). Electrons relaxed in $\mathrm{Sm}(\mathrm{II})$ to the ground state that lies $\sim 1 \mathrm{eV}$ below the Ce(IV) $5 \mathrm{~d}$ orbital energies. . This state was indefinitely stable. Pumping the Sm(II) with nearIR radiation induced back 
UCRL-ID-118561

page 21 of 50

electron transfer to $\mathrm{Ce}$ (IV) to give $\mathrm{Ce}(\mathrm{III})$, which then relaxed to its electronic ground state via green visible emission. The SrS:CeSm was ground into a powder, cast into a capillary, and fired. The capillary was place at the end of a single fiber, and probed with a YAG laser, though a pulsed or shuttered CW nearIR diode laser would also work. The probe exhibited good stopping power between 0.01 and $10 \mathrm{MeV}$. The signal verses dose rate or log(integrated dose) was linear, with exposures up to $1 \mathrm{Mrad} \gamma$ radiation.

A fiber optic detector utilizing color center damage in optical glass to monitor radiation yields has been reported.G.5 Transmission of light at $850 \mathrm{~nm}$ was monitored. Though the loss of transmission through a glass fiber was low at this wavelength, the effect could be magnified by coiling the fiber to long lengths around a cylindrical center support. Linear $\log$ (transmission) vs total dose up to $100 \mathrm{kRad}$ were observed, with a larger effect seen with longer windings. The effect was reversible to $70 \%$ by heating the fiber optic windings at $150^{\circ} \mathrm{C}$.

\subsubsection{ACTIVE DEVICES}

A double scintillating system fiber optic sensor has been described.G.2 An array of scintillators were coupled to commercially available fluorescent fibers. Emission from the scintillator in the green was used to excite the fiber, which emitted in the red. Radiation damage discolors in fiber in the blue, but the active region of the spectrum was unperturbed. A small array of CsI:Tl crystals were held perpendicular to the long axis of fluorescent fiber optics. The CsI:Tl was not hygroscopic, and scintillation efficiency was stable up to 24 kGy (2.4 Mrad). Small radiation damage effects were noted. The fibers responded to up to $3.5 \mathrm{Mrad}$.

The use of liquid scintillator filled tubes coupled to fiber optics for radiation detection has been investigated.G.3, G.4 The author's application was an array of fibers imaged on a CCD for particle tracking applications, but it would also work for counting total radiation yields. Tubes were made of glass capillaries, $\mathrm{n}_{\mathrm{D}}=1.49$, filled with 1-methylnaphthalene $\left(\mathrm{n}_{\mathrm{D}}=1.62\right)$ solutions of the scintillators R39 or R45, both of which were green emitters. The tubes were sealed on the tips of fiber optics, which then transmit light to CCD. In total Rad applications, a PMT or photodiode can be used. The system as described was used to track $5 \mathrm{GeV}$ hadrons. Virtually no attenuation due to radiation damage was noted over capillary lengths of $10 \mathrm{~cm}$ at up to $64 \mathrm{Mrad}$.

\subsection{BETA PARTICLES ( $\left.\beta^{-}\right)$}

$\beta$ - sensors are required for the detection and measurement of nuclides that decay by pure $\beta$ - (i.e. $\beta$ - only) decay. These nuclides include ${ }^{90} \mathrm{Sr}$ and ${ }^{99} \mathrm{Tc}$, 
both of which may be present in tank wastes. Sensors which can detect and discriminate $\beta$ - particles from other types of radiation have been reviewed.

A scintillating system, known as a "phoswich", based on two scintillators of differing stopping power of high energy particles has been described.E.1, E.6, E.8 A low stopping power crystal was set at the entrance of the detector, and stopped beta particles, resulting in emission. Gamma rays interacted in this crystal, caused emission, but were not stopped. Gamma passed into the second scintillator, was stopped, and caused emission. Light pulses were detected by a PMT and were discriminated on the basis on pulse shape analysis (PSA), which distinguishes between pulses based on differences in the temporal profile of the emission from each scintillator, i.e. prompt fluorescence versus long lived phosphorescence or phosphorescence of different lifetimes. Crystals were chosen with differing temporal profiles. When a high energy particle such as a gamma ray impinged upon the detector, emission pulses from both scintillators were received. A discrimination circuit was used to reject signals received from both of the scintillators, thereby rejecting gamma events. The crystals were chosen so that the gamma detector was the fast emission component. In this way the gamma signal could be used as a gate to reject the slower gamma signal from the beta detecting crystal. When a signal was received from only the beta scintillator, it was passed by the discriminator, and read into a pulse height analysis (PHA) circuit which gave the beta spectrum in terms of counts versus energy for detected particles.

In this particular application, a phoswich was used to detect $\mathrm{Sr}^{89} / \mathrm{Sr}^{90}$ in the presence of gamma emitters, i.e. pure beta emitters from beta/gamma emitters. E.8 The detector utilized a $\mathrm{CaF}_{2}(\mathrm{Eu})$ thin crystal $(7.6 \mathrm{~cm}$ diameter, $0.0635 \mathrm{~mm}$ thick covered with 0.0001 aluminized mylar window), $3.175 \mathrm{~mm}$ quartz dead layer, and a $6.35 \mathrm{~cm}$ thick $\mathrm{NaI}(\mathrm{Tl})$ crystal. The quartz dead layer was to ensure the stoppage of high energy $(>2.2 \mathrm{MeV})$ beta particles from reaching the $\mathrm{NaI}(\mathrm{Tl})$ crystal. The entire scintillator was mounted on a low background PMT, and was housed inside a stainless steel jacket. $\mathrm{Sr}^{89} / \mathrm{Sr}^{90}$ concentrations as low as $20 \mathrm{pCi} / \mathrm{L}\left(7.252 \times 10^{-6} \mathrm{~g} / \mathrm{L}\right)$ could be detected in the presence of beta/gamma emitters such as $\mathrm{Co}^{60}$ and $\mathrm{Cs}^{137}$. This report did not include PHA for spectral analysis of the samples, as interferents were strictly gamma/beta sources. Real samples measured at the Chinshan Nuclear Power Plant were reported.

This system can potentially be used in the penetrometer if smaller diameter crystals and a smaller, commercially available PMT is utilized in the design. A jacketing material of high stopping power would be necessary to protect the PMT from errant radiation and the crystals from reading radiation originating from other than the region of interest around the penetrometer tip. The power of the beta detecting scheme is the identification of pure beta emitting 
radionuclides such as $\mathrm{Sr}^{90}$ (beta $=0.546,2.284 \mathrm{MeV}$ ) and $\mathrm{Tc}^{99}$ (beta $=0.290$ $\mathrm{MeV}$ ). In addition, it can measure pure gamma spectra in the presence of beta by discriminating against slow component only pulses, and beta/gamma decay by PHA of the two component systems only, allowing identification of a broad array of nuclides potentially found in the tank environment.

A solid state phoswich detector has been described.E.5 In this device, the first scintillator was replaced by a thin, totally depleted Si detector. The Si was coated with Al mylar. Beta particles caused an event in both detectors, while gamma rays only effected the plastic scintillators. The depleted Si detectors measured the change in electron energy $(\mathrm{dE})$ of beta particles passing through the electron deficient silicon. Gamma rays illicited no response in this layer. Both were detected in the plastic scintillator (energy detector, E). The $\mathrm{dE}$ detector was $100 \mu \mathrm{m}$ thick, $50 \mathrm{~mm}^{2}$ in area. The E detector was BC-404 plastic and was a $25 \mathrm{~mm}$ radius by $20 \mathrm{~mm}$ thickness cylinder. The detector gave excellent rejection of photons to beta, $>225: 1$. The limitation was in energy resolution, due to the plastic scintillator. The device could also be operated as a gamma only detector in anticoincidence mode.

A detector consisting of a CdTe pn-junction diode, operating in photovoltaic mode with no applied voltage has been reported.E.2 The detector was run without low temperature cooling due to low dark current at $30^{\circ} \mathrm{C}$. This was due to much higher band gap than $\mathrm{Si}$ or Ge detectors. Thermostating was required to correct for temperature drift. The element size is small, $22 \times 22 \times$ $1.5 \mathrm{~mm}$. The detector had a large beta stopping power and low dark noise, so good $\mathrm{S} / \mathrm{N}$ was achievable at room temperature. Beta particles from a $85 \mathrm{Kr}$ source $(0.67 \mathrm{MeV})$ were used. Output was measured as the forward current flow caused by a radiation induced electric field in the device. The change in beta flux was measured as a function of the thickness of an aluminum shield for beta-ray thickness gauging. No spectral information was recorded in this study, just raw beta counts. The device was run continuously for 1000 hours with no detectable drift of the output current.

A semiconductor device to measure low energy beta particles based on an $\mathrm{HgI}_{2}$ xray detector was described.E.3 The device was reported as being capable of detecting particles down to $3.5 \mathrm{keV}$. The entire detecting unit was $1 \mathrm{~cm}^{2}$. Not much information was given, other than its use to detect tritium. A spectrum of $55 \mathrm{Fe}$ xrays at $5.9 \mathrm{keV}$ was shown. No mention was made of upper operating limits, nor temperature effects.

A detector based on high purity germanium (HPGe) was described.E.4 HPGe had an excellent stopping power for beta, as well as good energy resolution and energy calibration. A beryllium window was used, and a $16 \times 10 \mathrm{~mm} \mathrm{Ge}$ crystal. The application here was measurement of $\beta^{+}$particles up to $3.8 \mathrm{MeV}$. No details were given about the operating parameters for the solid state 
device. A disadvantage of HPGe is the need to operate the device at liquid nitrogen temperature.

\subsection{GAMMA $(\gamma)$ RAYS}

$\gamma$ ray sensors are required for the detection and measurement of nuclides that decay with the emission of excess nuclear energy by $\gamma$ decay. These nuclides include ${ }^{99} \mathrm{TC}$ and ${ }^{129} \mathrm{I}$. In addition, the daughters of the components of TRU waste relax via $\gamma$ emission, yielding a method of determining the presence and quantity of TRU waste. Sensors which can detect and discriminate $\gamma$ rays from other types of radiation have been reviewed.

A gamma ray phoswich, in which the fast component scintillator is the first detector element, and the slow component is second, has been described.E.7 The unit was used to detect low energy gamma rays, which would be stopped in first (fast $\mathrm{NaI}(\mathrm{Tl})$ ) layer of the detector. The second slow layer CsI(Na) would detect higher energy gamma. The device, developed at Los Alamos, was battery operated, utilizing a commercially available phoswich detector with a PSA for discrimination and a PHA for spectral analysis. Battery powered electronics were described. The PHA was a simple single channel analyzer. Pulses were gated on the slow component to ignore signals that originate in both crystals. It was used to measure and detect low energy gamma from ${ }^{241} \mathrm{Am}$ and ${ }^{239} \mathrm{Pu}$.

A GSO(Ce): $\mathrm{CsI}(\mathrm{Tl}): \mathrm{PMT}$ phoswich, utilizing $\mathrm{Gd}_{2} \mathrm{SiO}_{5}$ doped with $\mathrm{Ce}$, was described for low levels celestial gamma and xray detection.J.5 The design was a well shaped variation of a phoswich, where the GSO detector $(10 \mathrm{~mm}$ thick, $34 \mathrm{~mm}$ diameter) was embedded in an open ended well made of a bored CsI(Tl) (well depth $140 \mathrm{~mm}$ ). The gate scintillator was $80 \mathrm{~mm}$ of CsI(Tl), unbored. The purpose of the CsI shield was to eliminate background not directly incident on the GSO detector via PSA. Events that occurred on the GSO only were recorded. It was very sensitive to celestial gamma rays, and could be implemented as a directional gamma detector in the penetrometer.

A solid state detector based on synthetic diamond crystals doped with paramagnetic nitrogen (atomic) was described.J.1 Current pulses from the diamond under high voltage and gamma irradiation were amplified and converted to voltage output. The paper detailed the construction of a complete unit, which was battery operated and was $13.5 \times 3.4 \times 3.5 \mathrm{~cm}$ in dimensions for hand held operations and could be easily incorporated into the cone penetrometer. Circuitry read total dose rate of gamma, with a linear double log plot of response vs rate from 7.5 to $10000 \mu \mathrm{Gy} \mathrm{h} \mathrm{h}^{-1}$ from a ${ }^{137} \mathrm{Cs}$ source. Potential exists to convert the circuitry into a gamma ray 
UCRL-ID-118561

page 25 of 50

spectrometer. No details on sensitivity or interference from other types of radiation were given.

The application of $\mathrm{HgI}_{2}$ to gamma ray detection was described.J.2 $\mathrm{HgI}_{2}$ was chosen because of its large band gap for ambient temperature operation and high absorption of ionizing radiation. The goal was a lightweight, compact detection system. Two applications were described: the first used a $4 \times 4 \times 1.2 \mathrm{~cm}$ thick $\mathrm{HgI}_{2}$ detector at bias voltage of $2000 \mathrm{~V}$ to record gamma spectra directly. Energy resolution was $5 \%$ ( $30 \mathrm{keV}$ FWHM for $662 \mathrm{keV}{ }^{137} \mathrm{Cs}$ gamma ray). The second application was to use $\mathrm{HgI}_{2}$ as a photodetector coupled to a $2.5 \times 2.5 \mathrm{~cm}^{2}$ CsI(TI) scintillator crystal. The second application removed the bulk of a PMT and the electronics associated with it. Few technical details were given.

A brief survey of beta and gamma ray detector elements was described.J.4 The salient feature of the survey was a description of BGO, bismuth germanate, $\mathrm{Bi}_{4} \mathrm{Ge}_{3} \mathrm{O}_{12}$, commercially available, which has a high density and large atomic number, therefore one of the better absorbers for radiation. It is not hygroscopic, but lower light yields than $\mathrm{NaI}(\mathrm{Tl})$, therefore lower energy resolution are obtained. Emission yield falls off with increasing temperature, so cooling may be required.

Several geometries of a CdTe detector for gamma rays were described.J.6 Room temperature operation of a gamma ray detector was the goal. The authors examined several different geometries of detectors in terms of resolution and efficiency. The best results were planar devices utilizing post collection electronic pulse processing to reduce noise levels.

\subsection{CONCLUSIONS}

A wide array of sensors exist for the characterization needs of the in-tank cone penetrometer. The sensors covered in the review represent classes of detection schemes which may be considered for penetrometer deployment. The optical spectroscopic techniques, including Raman spectroscopy, offer a superior interrogation tool in that no direct contact between the sensor and the tank waste materials are necessary. Many of the electronic and colorimetric techniques require a physical or chemical interaction between tank matrices and the sensor element, offering a challenging engineering problem for the final deployment of such sensors in the harsh environment of the Hanford underground storage tanks.

\subsection{ACKNOWLEDGMENT}

The work at Lawrence Livermore National Laboratory (LLNL) was supported by Sherry M. Gibson, Program Manager of the Underground Storage Tank 
UCRL-ID-118561

page 26 of 50

Integrated Demonstration, EM-50, Office of Technology Development, U.S. Department of Energy.

\subsection{REFERENCES}

\section{A) Ferrocyanide Detectors}

1) Geraty, Suzanne M., Arrigan, Damien W.M., and Vos, Johannes G., "The Use of Electrodes Coated with Ruthenium-Containing Polymers as Sensors for Iron(II)," Anal. Chem. Symp. Ser,., 25, 303-8, 1986.

\section{B) Nitrate Detectors}

1) Kang, Sung Chul, Lee, Keun-Sun, Kim, Jin-Doo, and Kim, Kang-Jin, "Polypyrrole Modified Electrode as a Nitrate Sensor," Bull. Korean Chem. Soc., 11 (2), 124-6, 1990.

2) Fogg, Arnold G., Scullion, S. Paul, Edmonds, Tony E., and Birch, Brian J., "Direct Reductive Amperometric Determination of Nitrate at a Copper Electrode Formed In Situ In a Capillary-fill Sensor Device," Analyst, 116, 5739, 1991.

3) Lumpp, R., Reichert, J., and Ache., H. J., "An optical sensor for the detection of nitrate," Sensors and Actuators B, 7, 473-5, 1992.

4) Heinzmann, G., Czolk, R., and Ache, H. J., "Investigation of the stability of an optochemical nitrate sensor," Sensors and Actuators B, 18-19, 47-50, 1994.

5) Ebdon, Les, King, Beverley A., and Corfield, George C., "Nitrate Ion Selective Electrodes with Covalently Bound Sensors," Anal. Proc., 22, 354-6, 1985.

6) Ebdon, Les, Braven, Jim., and Frampton, Nicholas C., "Nitrate-selective Electrodes With Polymer Membranes Containing Immobilised Sensors," Analyst, 115, 189-93, 1990.

\section{C) Hydrogen Detectors}

1) Mingmei, $\mathrm{Wu}$, and Yufang, Ren, "A new hydrogen sensor with rare earth complex fluoride," Sensors and Actuators B, 8, 179-80, 1992.

2) Tan, Y., and Tan, T. C., "Characteristics and Modeling of A Solid State Hydrogen Sensor," J. Electrochem. Soc., 141 (2), 461-7, 1994. 
3) Miura, Norio, Harada, Tatsuro, Shimizu, Youichi, and Yamazoe, Noboru, "Cordless Solid-state Hydrogen Sensor Using Proton-conductor Thick Film," Sensors and Actuators B, 1, 125-9, 1990.

4) De Angelis, L., Maimone, A., Modica, L., Alberti, G., and Palombari, R., "A New Hydrogen Sensor with Pellicular Zr Phosphate as Proton Conductor," Sensors and Actuators B, 1, 121-4, 1990.

5) Mandelis, Andreas, and Christofides, Constantinos, "Surface hydrogenpalladium studies using a new photopyroelectric detector," J. Vac. Sci. Technol. A, 8 (6), 3980-3, 1990.

6) Pauss, A., Samson, R., Guiot, S., and Beauchemin, C., “Continuous Measurement of Dissolved $\mathrm{H}_{2}$ in an Anaerobic Reactor Using a New Hydrogen/Air Fuel Cell Detector," Biotech. and Bioeng., 35, 492-501, 1990.

7) Iwahara, H., Uchida, H., Ogaki, K., and Nagato, H., "Nernstian Hydrogen Sensor Using $\mathrm{BaCeO}_{3}-\mathrm{Based}$, Proton-Conducting Ceramics Operative at $200^{\circ}-$ 900 C," J. Electrochem. Soc., 138 (1), 295-9, 1991.

8) Yadava, Lallan, Dwivedi, R., and Srivastava, S. K., "A Titanium DioxideBased MOS Hydrogen Sensor," Solid-State Electro., 33 (10), 1229-34, 1990.

9) Fang, Y. K., Hwang, S. B., Lin, C. Y., Lee, C. C., "Trench Pd/Si metal-oxidesemiconductor Schottky barrier diode for a high sensitivity hydrogen gas sensor," Appl. Phys. Lett., 57 (25), 2686-8, 1990.

10) Christofides, Constantinos, Mandelis, Andreas, and Enright, John, "Optimization of the Photopyroelectric Hydrogen Gas Sensor: Geometry and Temperature Measurements," Jap. J. Appl. Phys., 30 (11A), 2916-20, 1991.

11) Dutta, A., Chaudhuri, T. K., and Basu, S., "Deposition and characterization of zinc oxide thin films for hydrogen sensor devices," Mat. Sci. and Eng., B14, 31-5, 1992.

12) Lechuga, L. M., Calle, A., Golmayo, D., and Briones, F., "Hydrogen Sensor Based on a Pt/GaAs Schottky Diode," Sensors and Actuators B, 4, 515-8, 1991.

13) Adler-Golden, Steven M., Goldstein, Neil, Bein, Fritz, Matthew, Michael W., Gersh, Michael E., Cheng, Wai K., and Adams, Frederick W., "Laser Raman sensor for measurement of trace-hydrogen gas," Appl. Optics, 31 (6), 831-5, 1992.

14) Butler, Michael A., "Fiber Optic Sensor for Hydrogen Concentrations near the Explosive Limit," J. Electrochem. Soc., 138 (9), L46-7, 1991. 
UCRL-ID-118561

page 28 of 50

15) Chehab, S. F., Canaday, J. D., Kuriakose, A. K., Wheat, T. A., and Ahmad, A., "A hydrogen sensor based on bonded hydronium NASICON," Solid-State Ionics, 45, 299-310, 1991.

16) Zvereva, N. P., Lazarev, S. D., Teterin, N. E., Filippov, V. I., Yakimov, S. S., and Goncharov, V. Ya., "A Method for Determination of Hydrogen Content in Uranium Dioxide Samples Using a Semiconductor Sensor," J. Radioanal. and Nuc. Chem., Art., 147 (1), 197-200, 1991.

17) Babichev, A. P., Babulevich, N. E., Lazarev, S. D., and Yakimov, S. S., "Use of a Sensor Based on a MDS Structure for Determination of Hydrogen in Solids," Zhurnal Analiticheskoi Khimii, 45 (7), 1317-22, 1990.

18) Oh, Yong-su, Hamagami, Junichi, Watanabe, Yuichi, and Takata, Masasuke, "Preparation and characterization of an optically-detectable hydrogen gas sensor consisting of $\mathrm{Pd} / \mathrm{WO}_{3}$ thin films," Sensors and Actuators $B, 13-14,547-8,1993$.

19) Camanzi, A., Colilli, R., Pelacani, A., Severi, M., Solmi, S., and Maccagnani, $\mathrm{P}$. ., "A novel $\mathrm{Pd}-\mathrm{SiN}_{\mathrm{x}} \mathrm{O}_{\mathrm{y}}$ hydrogen sensor of high stability and sensitivity," Sensors and Actuators B, 5, 181-3, 1991.

20) Bachiocchi, M., Bearzotti, A., Gentili, M., Lucchesini, A., Caliendo, C., Verona, E., d'Amico, A., "Cu/Pd Thin-film Thermopile as a Temperature and Hydrogen Sensor," Sensors and Actuators, A21-A23, 631-5, 1990.

21) Pecora, A., Fortunato, G., Carluccio, R., and Sacco, S., "Hydrogenated amorphous silicon based Light-Addressable Potentiometric Sensor (LAPS) for hydrogen detection," J. Non-Crystal. Solids, 164-166, 793-6, 1993.

22) Hughes, R. C., Buss, R. J., Reynolds, S. W., Jenkins, M. W., and Rodriquez, J. L., "Wide Range $\mathrm{H}_{2}$ Sensor Using Catalytic Alloys," Proceedings of the Electrochemical Society, Chemical Sensors II., PV93-7, 556-564, 1993.

\section{D) Ionic Species Detectors}

1) Mullen, Ken I., Wang, Dao-Xin, Crane, L. Gayle, and Carron, Keith T., "Trace Detection of Ionic Species with Surface Enhanced Raman Spectroscopy," Spectroscopy, 7 (6), 24-32, 1992.

2) Zusman, Rivka, Rottman, Claudio, Ottolenghi, Michael, and Avnir, David, "Doped Sol-Gel Glasses as Chemical Sensors," J. Non-Crystal. Solids, 122, 1079, 1990.

3) Kurokawa, Y., Imai, Y., Sasaki, T., and Maeda, T., "Surface-Enhanced Raman Spectroscopic Detection of $\mathrm{CO}_{3}{ }^{2-}, \mathrm{SO}_{3}{ }^{2-}$, and Nucleic Acid Bases Using 
UCRL-ID-118561

page 29 of 50

Polyvinal Alcohol Film Doped with Ag Fine Particles," Anal. Biochem., 209, 247-50, 1993.

4) Dong, Shaojun, Sun, Zhisheng, and Lu, Ziling, "A New Kind of Chemical Sensor based on a Conducting Polymer Film," J. Chem. Soc., Chem.

Commun., 993-5, 1988.

5) Lev, Ovadia, Kuyavskaya, Berta Iosefson, Gigozin, Ida, Ottolenghi, Michael, and Avnir, David, "A high-sensitivity photometric method based on doped Sol-Gel glass detectors: determination of sub-ppb divalent iron," Fresenius $J$. Anal. Chem., 343, 370-2, 1992.

6) Cobben, Peter L. H. M., Egberink, Richard J. M., Bomer, Johan G., Bergveld, Piet, Verboom, Willem, and Reinhoudt, David N., "Transduction of Selective Recognition of Heavy Metal Ions by Chemically Modified Field Effect Transistors (CHEMFETs)," J. Am. Chem. Soc., 114, 10573-82, 1992.

E) $\beta$ Detectors

1) Wang, Chu-Fand, Lee, Jeng-Horng, and Chiou, Horng-Jye, "Rapid Determination of Sr-89/Sr-90 in Radwaste by Low-level Background Beta Counting System," Appl. Radiat. Isot., 45 (2), 251-6, 1994.

2) Wada, Morio, Suzuki, Jun-Ichi, and Ozaki, Yuzo, "Cadmium Telluride $\beta$ Ray Detector," Sensors and Actuators, 19, 227-36, 1989.

3) Shah, K. S., Squillante, M. R, and Entine, G., " $\mathrm{HgI}_{2}$ Low Energy Beta Particle Detector," IEEE Trans. Nucl. Sci., 37 (2), 152-4, 1990.

4) Osa, A., Ikuta, T., Shibata, M., Miyachi, M., Yamamoto, H., Kawade, K., Kawase, Y., and Ichikawa, S., "Measurement of $\beta^{+}$-ray maximum energy with an HPGe detector," Nuc. Inst. and Method. in Phys. Res. A, 332, 169-74, 1993.

5) Horowitz, Y. S., Hirning, C. R., Yuen, P., and Aikens, M., "Beta ray spectroscopy based on a plastic scintillation detector/silicon surface barrier detector coincidence telescope," Nuc. Inst. and Method. in Phys. Res. A, 338, 522-33, 1994.

6) Wogman, N. A., Brodzinski, R. L., and Brown, D. P., "Evaluation of a Phoswich Detector for the In Situ Analysis of ${ }^{90} \mathrm{Sr}_{r}$ " IEEE Trans. Nucl. Sci., NS$27(1), 733-41,1980$.

7) Umbarger, C. J., and Wolf, M. A., "A Battery Operated Portable Phoswich Detector for Field Monitoring of Low Levels of Transuranic Contaminants," Nucl. Instr. and Meth., 155, 453-7, 1978. 
UCRL-ID-118561

page 30 of 50

8) Wilkinson, D. H., "The Phoswich--A Multiple Phosphor," Rev. Sci. Instr., $23(8), 414-7,1952$.

F) Photochromic Radiation Detectors

1) Ouseph, P. J., and Groskreutz, H. E., "Photochromic Materials as Radiation Detectors," Nucl. Instr. and Meth., 113, 469-71, 1973.

2) Ouseph, P. J., "Energetic Heavy-Particle Detection by Photochromic Material," Phys. Rev., Letters, 30 (23), 1162-5, 1973.

\section{G) Fiber Optic Radiation Detectors}

1) Soltani, Peter K., and Pierce, Gregory, "Novel Fiber Optic Radiation Sensor for In Vivo Dosimetry," SPIE Fib. Opt. Med. and Fluor. Sens. and Appl., 1648, 71-82, 1992.

2) Laguesse, M., and Bourdinaud, M., "Radiation sensor based on inorganic scintillator with fibre readout for high energy radiography," Sensors and Actuators A, 32, 464-9, 1992.

3) Cianfarani, C., Duane, A., Fabre, J. -P., Frenkel, A., Golovkin, S. V., Gorin, A. M., Harrison, K., Kozarenko, E. N., Kushnirenko, A. E., Ladygin, E. A., Martellotti, G., Medvedkov, A. M., Nass, P. A., Obudovski, V. P., Penso, G., Petukhob, Yu. P., Siegmund, W. P., Tyukov, V. E., and Vasilchenko, V. G., "A high-resolution detector based on liquid-core scintillating fibres with readout via an electron-bombarded charge-coupled device," Nuc. Inst. and Method. in Phys. Res. A, 339, 449-55, 1994.

4) Adinolfi, M., Angelini, C., Cardini, A., Cianfarani, C., Da Via, C., Duane, A., Fabre, J. -P., Flaminio, V., Frenkel, A., Golovkin, S. V., Gorin, A. M., Gruwe, M., Harrison, K., Kanerva, M., Kozarenko, E. N., Kushnirenko, A. E., Martellotti, G., McEwen, J. G., Morrison, D. R. O., Penso, G., Peresypkin, A. I., Roda, C., Websdale, D. M., Wilquet, G., and Zaichenko, A. A., "Progress on high-resolution tracking with scintillating fibres: a new detector based on capillaries filled with liquid scintillator," Nuc. Inst. and Method. in Phys. Res. A, 315, 177-81, 1992.

5) Suter, J. J., Poret, J. C., and Rosen, M., "Fiber Optic Ionizing Radiation Detector," IEEE Trans. Nucl. Sci., 39 (4), 674-9, 1992.

\section{H) $\mathrm{pH}$ Detectors}

1) Wolthuis, Roger, McCrae, David, Saaski, Elric, Hartl, James, and Mitchell, Gordon, "Development of a Medical Fiber-Optic pH Sensor Based on Optical Absorption," Trans. Biomed. Eng., 39 (5), 531-7, 1992. 
2) Grattan, K. T. V., Badini, G. E., Palmer, A. W., and Tseung, A. C. C., "Use of Sol-Gel Techniques for Fibre-optic Sensor Applications," Sensors and Actuators A, 25-27, 483-7, 1991.

3) Rottman, C., Ottolenghi, M., Zusman, R., Lev, O., Smith, M., Gong, G., Kagan, M. L., and Avnir, D., "Doped Sol-Gel glasses as pH sensors," Materials Letters, 13, 293-8, 1992.

4) Jones, Thomas P., Coldiron, Shelley J., Deninger, William J., and Porter, Marc D., "A Field-Deployable Dual-Wavelength Fiber-Optic pH Sensor Instrument Based on Solid-State Optical and Electrical Components," App. Spect., 45 (8), 1271-7, 1991.

\section{I) Reviews}

1) Janata, Jirí, Josowicz, Mira, and DeVaney, D. Michael, "Chemical Sensors," Anal. Chem., 66 (12), 207R-28R, 1994.

2) Janata, J., "Chemical Sensors," Anal.Chem., 64 (12), R196-R219, 1992.

3) Janata, J., "Chemical Sensors," Anal. Chem., 62 (12), R33-R44, 1990.

4) Niessner, R., "Chemical Sensors for Environmental Analysis," Trac-Trends In Anal. Chem., 10 (10), 310-6, 1991.

5) Fleet, B., and Gunasingham, H., "Electrochemical Sensors for Monitoring Environmental Pollutants," Talanta, 39 (11), 1449-57, 1992.

\section{J) $\gamma$ Detectors}

1) Grobbelaar, J. H., Burns, R. C., Nam, T. L., and Keddy, R. J., "Miniaturized radiation detector with custom synthesized diamond crystal as sensor," Nuc. Inst. and Method. in Phys. Res.., B61, 553-9, 1991.

2) van den Berg, L., "Recent developments in mercuric iodide technology at EG\&G Energy Measurements, Inc., Santa Barbara Operations," Nuc. Inst. and Method. in Phys. Res.., A322, 453-6, 1992.

3) Sun, H. C., Zhao, J. Q., Zhang, R. X., Zhou, C. L., Ni, H. F., Wu, S. Y., Wuru, G. S., Wang, J. S., Han, R. J., Han, B. H., Ho, G. K., Liang, H. P., Zhang, Q. X., Li, Z. C., Cheng, Z. H., and Xia, Z. Q., "Natural Gamma-ray Spectrometer with HPGe Detector for Petroleum Well Logging," Nucl. Geophys., 5 (1/2), 91-4, 1991. 
UCRL-ID-118561

page 32 of 50

4) Knoll, Glenn F., "Some Recent Developments in Charged Particle and Gamma Ray Detectors," Nuc. Inst. and Method. in Phys. Res.., B24/25, 1021-7, 1987.

5) Kamae, T., Gunji, S., Hirayama, M., Kubo, H., Miyazaki, S., Saito, Y., Sekimoto, Y., Suzuki, K., Takahashi, T., Tamura, T., Tanaka, M., Yamaoka, N., Yamagami, T., Nomachi, M., and Murakami, H., "Well-Type Phoswich Counters for Low-Flux X-Ray/ $\gamma$-Ray Detection," SPIE Gamma-Ray Detectors, 1734, 2-13, 1992.

6) Richter, M., and Siffert, P., "High resolution gamma ray spectroscopy with CdTe detector systems," Nuc. Inst. and Method. in Phys. Res.., A322, 529-537, 1992.

\section{K) Ammonia/Ammonium Detectors}

1) Fehér, Miklos, Martin, Philip A., Rohrbacher, Andreas, Soliva, Anton M., and Maier, John P., "Inexpensive near-infrared diode-laser-based detection system for ammonia," Applied Optics, 32 (12), 1993.

2) Kar, Satyajit, and Arnold, Mark A., "Air-Gap Fiber-Optic Ammonia Gas Sensor," Talanta, 40 (5), 757-60, 1993.

3) Dogan, S., Akbulut, U., Yalcin, T., Suzer, S., and Toppare, L., "Conducting polymers of aniline II. A composite as a gas sensor," Synth. Metals, 60, 27-30, 1993.

4) Lechuga, L. M., Calle, A., Golmayo, D., Briones, F., De Abajo, J., and De La Campa, J. G., "Ammonia sensitivity of $\mathrm{Pt} / \mathrm{GaAs}$ Schottky barrier diodes. Improvement of the sensor with an organic layer," Sensors and Actuators B, 8, 249-52, 1992.

5) Maekawa, Tomoki, Tamaki, Jun, Miura, Norio, and Yamazoe, Noboru, "Gold-Loaded Tungsten Oxide Sensor for Detection of Ammonia in Air," Chem. Lett., 639-42, 1992.

6) Moseley, P. T., and Williams, D. E., "A Selective Ammonia Sensor," Sensors and Actuators, B1, 113-5, 1990.

\section{L) Cyanide Detectors}

1) Bentley, Ann E., and Alder, John F., "Optical Fibre Sensor for Detection of Hydrogen Cyanide in Air: Part 1," Anal. Chim. Acta, 222, 63-73, 1989.

2) Jawad, Sajad M., and Alder, John F., "Optical Fibre Sensor for Detection of Hydrogen Cyanide in Air: Part 2," Anal. Chim. Acta, 246, 259-66, 1991. 
UCRL-ID-118561

page 33 of 50

\section{M) Isotope References}

1) Browne, Edgardo, Dairiki, Janis M., and Doebler, Raymond E.,Table of Isotopes, 7th Ed., John Wiley \& Sons, Inc., New York, 1978.

\section{N) Volitile Organic Compund Detectors}

1) Wang, Xiaodong, Yee, Sinclair, and Carey, Patrick, "An integrated array of multiple thin-film metal oxide sensors for quantification of individual components in organic vapor mixtures," Sensors and Actuators B, 13-14, 458$61,1993$.

2) Giuliani, J. F., "Integrated Optical Chemical Vapor Microsensors," Sensors and Actuators, 15, 25-31, 1988.

3) Poghossian, A. S., Abovian, H. V., Avakian, P. B., Mkrtchian, S. H., and Haroutunian, V. M., "Bismuth Ferrites: New Materials for Semiconductor Gas Sensors," Sensors and Actuators B, 4, 545-9, 1991.

4) Sundgren, H., Winquist, F., Lukkari, I., and Lundström, I., "Artificial neural networks and gas sensor arrays: quantification of individual components in a gas mixture," Meas. Sci. Technol., 2, 464-9, 1991.

5) Amati, D., Arn, D., Blom, N., Ehrat, M., Saunois, J., and Widmer, H. M., "Sensitivity and selectivity of surface acoustic wave sensors for organic solvent vapour detection," Sensors and Actuators B, 7, 587-91, 1992.

6) Utsunomiya, Koh, Nakagawa, Masuo, Chikamori, Shinji, Kohata, Masaki, Tomiyama, Tsuyoshi, Yamamoto, Isao, Wada, Tomonori, Yamashita, Nobuhiko, and Yamashita, Yoshihiko, "Photoluminescence study of adsorption-luminescent $\mathrm{Al}_{2} \mathrm{O}_{3}$ sensor for determining odor substances in air," SPIE Adv. in Fluores. Sens. Tech., 1885, 93-100, 1993.

7) Milanovich, Fred P., Brown, Steve B., Colston, Billy W., "Penetrometer Compatible, Fiber Optic Sensor for Continuous Monitoring of Chlorinated Hydrocarbons- Field Test Results," Proc. Electrochem. Soc., Chemical Sensors II, P93-7, 643-647, 1993.

\section{O) Nitrite Detectors}

1) Doherty, Andrew P., Forster, Robert J., Smyth, Malcolm R., and Vos, Johannes G., "Development of a sensor for the detection of nitrite using a glassy carbon electrode modified with the electrocatalyst

[Os(bipy) $\left.)_{2}(\mathrm{PVP})_{10} \mathrm{Cl}\right] \mathrm{Cl}$," Anal. Chim. Acta, 255, 45-52, 1991. 
2) Gao, Zhiqiang, Zi, Mingxian, Zhang, Yimin, Wang, Guangqiang, and Zhao, Zaofan, "Electrochemical Sensor of Nitrite Based on an Inorganic Film Modified Glassy Carbon Electrode," Mikrochim. Acta, 111, 63-70, 1993.

3) Cox, James A., and Kulesza, Pawel J., "A Selective Electrolytic Sensor for Nitrite Based on a Modified Platinum Electrode," Anal. Chim. Acta, 158, 335$341,1984$.

\section{P) Mercury Detectors}

1) Srivastava, S. K., Sahgal, Vandana, and Vardhan, Harsh, "A solid inorganic gel membrane sensor for mercury," Sensors and Actuators B, 13-14, 391-5, 1993.

2) Spassov, L., Yankov, D. Y., Mogilevski, A. N., and Mayorov, A. D., "Piezoelectric sorption sensor for mercury vapors in air using a quartz resonator," Rev. Sci. Instrum., 64 (1), 1993.

\section{Q) DOE Publication}

1) "Underground Storage Tank Integrated Demonstration (UST-ID): Technology Summary," Office of Environmental Management/Office of Technology Development, February, 1994, DOE/EM-0122P.

2) "Uranium in Soils Integrated Demonstration: Technology Summary," Office of Environmental Management/Office of Technology Development, March, 1994, DOE/EM-0148P.

3) "Characterization, Monitoring, and Sensor Technology Integrated Program (CMST-IP): Technology Summary," Office of Environmental Management/Office of Technology Development, April, 1994, DOE/EM0156T.

4) "Innovation Investment Area: Technology Summary," Office of Environmental Management/Office of Technology Development, March, 1994, DOE/EM-0146P.

5) "Review of Instrumentation and Sensors- Cone Penetrometer Applications: Task 6 Report," April, 1994, DOE-HWP.149

6) "Literature Search, Review, and Compilation of Data for Chemical and Radiochemical Sensors-Task 1 Report," January, 1993, DOE/HWP-130.

7) "Literature Search, Review, and Compilation of Data for Chemical and Radiochemical Sensors- Task 2 Report," April, 1993, DOE/HWP-133. 
UCRL-ID-118561

page 35 of 50

8) "Literature Search, Review, and Compilation of Data for Chemical and Radiochemical Sensors-Task 3 Report," October, 1993, DOE/HWP-138.

9) "Literature Search, Review, and Compilation of Data for Chemical and Radiochemical Sensors- Task 4 Report," December, 1993, DOE/HWP-144.

10) "Literature Search, Review, and Compilation of Data for Chemical and Radiochemical Sensors- Task 5 Report," January, 1994, DOE/HWP-148.

\section{R) Commercial References}

1) "Product/Literature Showcase," RED, May, 1994.

2) "1994 Buyer's Guide," Sensors: The Journal of Machine Perception, May, 1994.

3) "1993-1994 Labguide," Analytical Chemistry, August, 1993.

4) "The Buyers Guide 1994," Laser Focus World, December 1993. 


\section{APPENDIX A: ISOTOPE DECAY SCHEMES}

\section{Energy in $\mathrm{MeV}$}
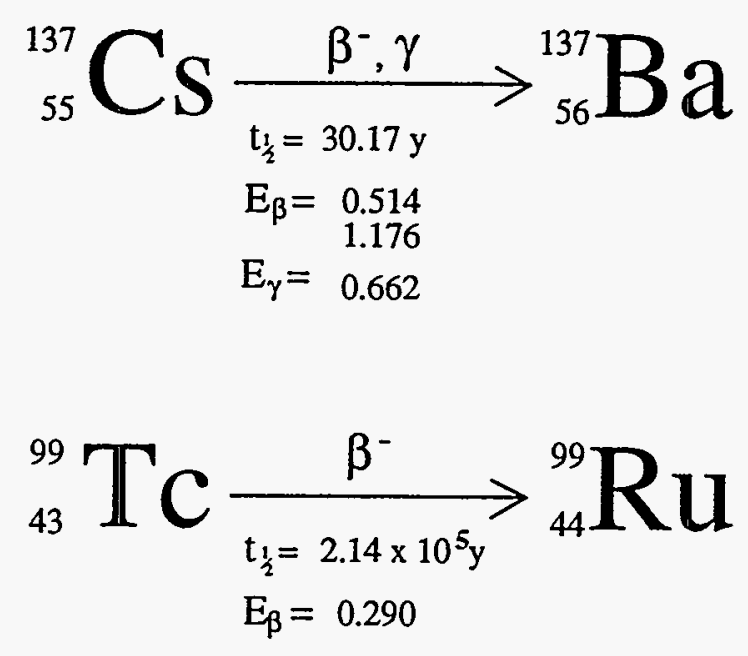

$$
\begin{aligned}
& \left.{ }_{53}^{129}\right\rfloor \frac{\beta^{-}, \gamma}{t_{\frac{1}{2}=1.57 \times 10^{7 y}}}{ }_{54}^{129} \backslash \Gamma \\
& E_{\beta}=0.150 \\
& E_{\gamma}=0.040
\end{aligned}
$$

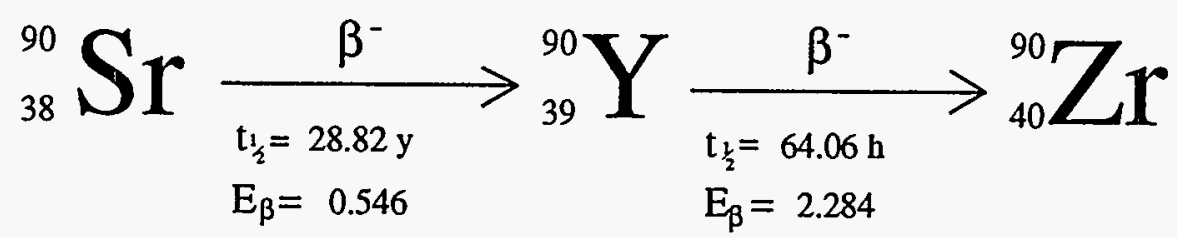


UCRL-ID-118561

page 37 of 50

\section{Energy in $\mathrm{MeV}$}

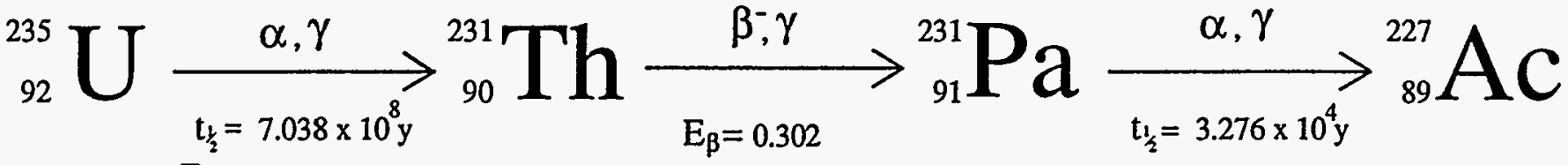

$$
\begin{aligned}
& \mathrm{E}_{\alpha}=4.397 \\
& \mathrm{E}_{\gamma}=0.084 \\
& E_{\alpha}=5.058 \\
& \mathrm{E}_{\gamma}=0.186 \\
& E_{\gamma}=0.046
\end{aligned}
$$

\begin{tabular}{|c|c|c|}
\hline$\alpha, \gamma$ & $\alpha, \gamma$ & $\beta^{-}$ \\
\hline$E_{\gamma}=0.271$ & $E_{\gamma}=0.439$ & $L_{\beta}-$ \\
\hline
\end{tabular}

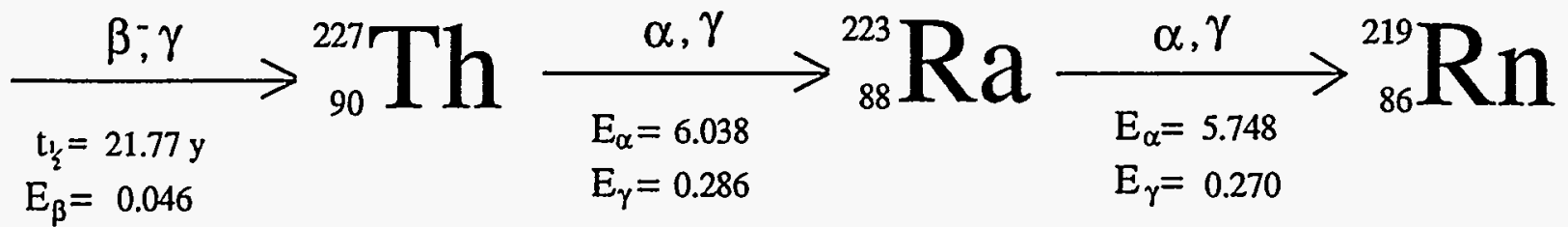

$E_{\gamma}=0.009$

$\underset{\substack{E_{\alpha}=6.623 \\ E_{\gamma}=0.351}}{\stackrel{\alpha . \gamma}{207}\rceil \Gamma \prod} \underset{81}{E_{\beta}=1.431}{ }_{82}^{207} \mathbf{P} \mathbf{D}$


UCRL-ID-118561

page 38 of 50

\section{Energy in $\mathrm{MeV}$}
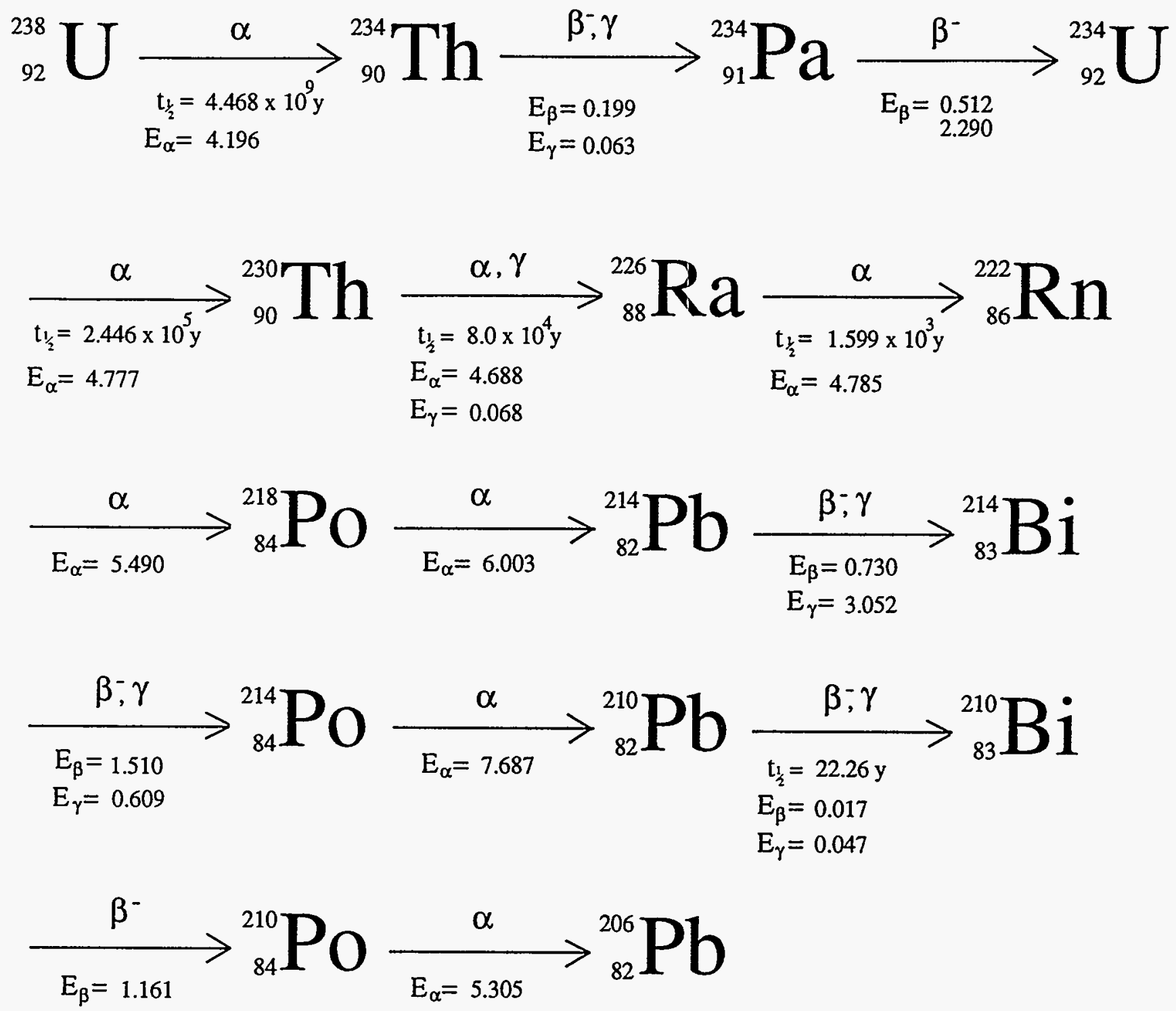


\section{Energy in $\mathrm{MeV}$}
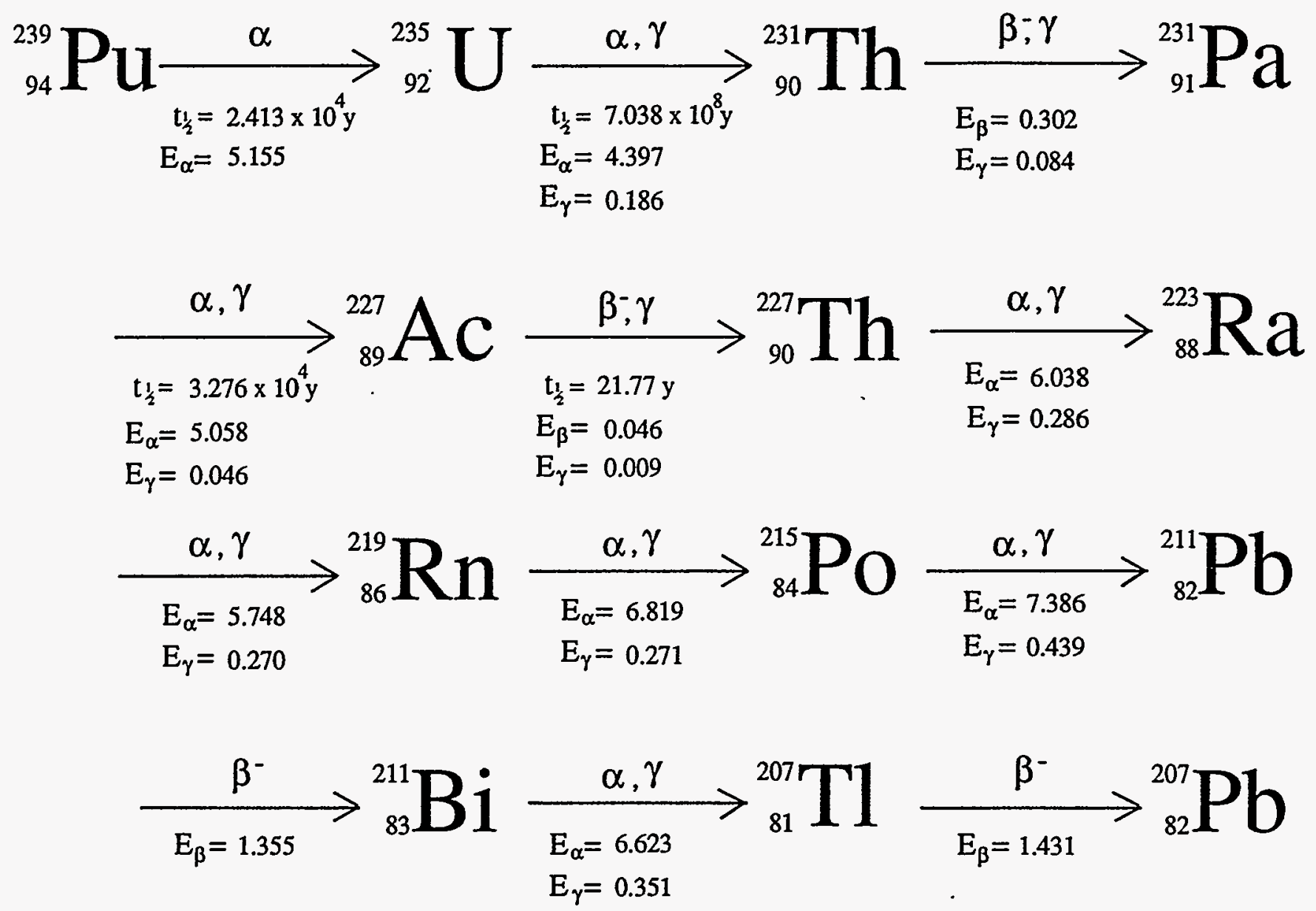


\section{Energy in $\mathrm{MeV}$}

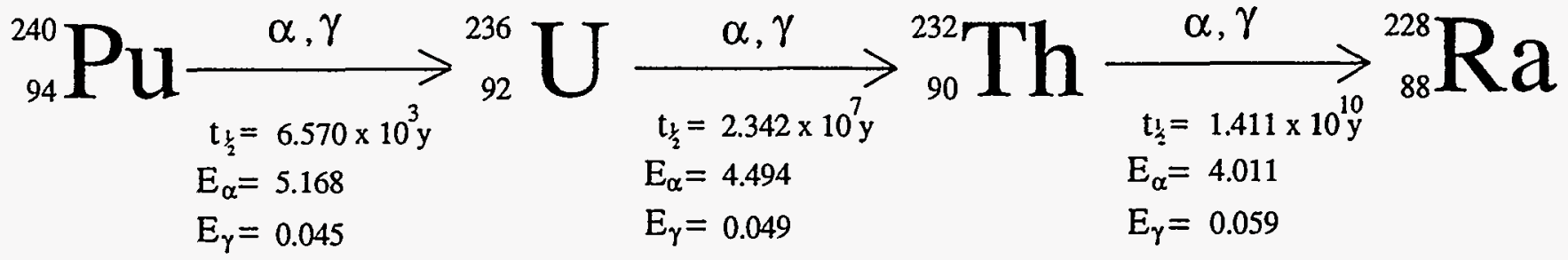

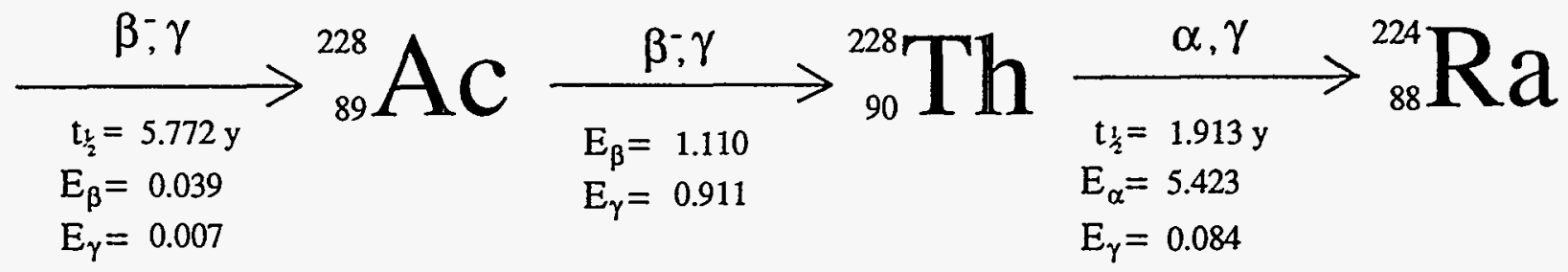

$$
\begin{aligned}
& { }_{E_{\alpha}=5.686}^{\alpha}{ }_{86}^{220} \mathbf{R} \longrightarrow \frac{\alpha}{E_{\alpha}=6.288}>_{84}^{216} \mathbf{D} \frac{\alpha}{E_{\alpha}=6.779}>_{82}^{212} \mathbf{D}
\end{aligned}
$$

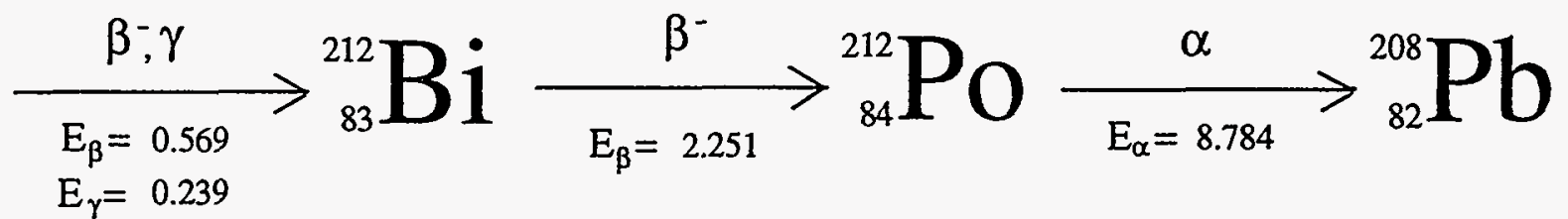




\section{APPENDIX B: $\quad$ DEPARTMENT OF ENERGY MONITORING TECHNOLOGY DEVELOPMENT SUMMARY}

The following summary provides information on technologies under development throughout the DOE complex that are currently funded under the Integrated Demonstrations and Integrated Programs of DOE/OTD. The emphasis of the projects listed below are sensor and detector development that may potentially be integrated with a cone penetrometer for in tank chemical analysis. Inclusion in this section is not meant to be an endorsement of the technology by the author, but rather as an information service to the reader. Detailed technology summaries of DOE/OTD projects can be found in references Q.1-Q.4.

Underground Storage Tank Integrated DemonstrationQ.1

Fiber Optic Near Infrared Spectrometer System

Project by Westinghouse Savannah River Company to develop a fiber optic probe to accurately measure the moisture content of UST waste in both a hot cell and tank environments. The sensor monitors the attenuation of reflected near infrared light due to absorbance losses by water vibrational overtones.

Fiber Optic Laser Raman Spectroscopies for Tank Waste Characterization

This is a joint project involving WSRC, WHC, LLNL, FSU, NRL, and USC to develop a fiber optic probe to characterize and measure molecular chemical constituents of UST waste core sections. The sensor utilizes laser Raman Spectroscopy to characterize samples via their vibrational spectral fingerprint.

Uranium in Soils Integrated DemonstrationQ.2

Improved In Situ Gamma-Ray Spectrometer

Work is being performed at PNL to develop a compact in situ gamma spectrometer for use in characterizing radionuclide contaminated sites. The spectrometer is based on a liquid nitrogen cooled, commercially available HPGe detector interfaced with a miniature, modular, battery operated multichannel analyzer and data reduction software. 
UCRL-ID-118561

page 42 of 50

Characterization, Monitoring, and Sensor Technology. Integrated ProgramQ.3

Site Characterization and Penetrometer System (SCAPS)

Work coordinated by Argonne National Lab for the operation and maintenance of a penetrometer system. A major task in this project involves the technical evaluation of all sensors, samplers, and in situ analyses developed for use with the penetrometer in terms of their performance and operating requirements set forth by the potential end user.

Time Domain Reflectometry and Fiber-Optic Probes for the Cone Penetrometer

SNL is designing and testing fiber optic probes and penetrometer tips for use in subsurface soil measurements. Specific systems are for the fiber optic measurement of soil pore pressure, a TDR probe for moisture measurements, and chemical sensors for penetrometer.

Multi-Analyte, Single-Fiber, Optical Sensor

LLNL and Tufts University are developing and testing a fiber optic probe for the simultaneous measurement of several analytes. The probe technology is based on individual, species selective sensors chemically bound to a $500 \mu \mathrm{m}$ or less diameter coherent imaging fiber optic. Target compounds include but are not limited to $\mathrm{pH}, \mathrm{Al}^{3+}, \mathrm{UO}_{2}{ }^{2+}$, and hydrocarbons (nonspecific).

Sol-Gel Indicator Program

The Savannah River Technology Center is developing Sol Gel sensors coupled with a portable fiber optic spectrometer for the measurement of solution phase chemical species. The species of interest include but are not limited to $\mathrm{pH}$, Uranium, and heavy metal ions.

Portable, Real-Time Monitoring Systems for Volatile Organics

SNL has developed and demonstrated SAW device for the sensitive, down well and in off-gas stream detection of VOCs, in particular $\mathrm{CCl}_{4}$ at the Hanford site. The portable acoustic wave sensor (PAWS) was shown to be stable over time, and sensitive to $\mathrm{CCl}_{4}$ from 10 to $100000 \mathrm{ppm}$ in air, with no water interference. The sensor responds rapidly (seconds) and reversibly.

Chlorinated and Aromatic Hydrocarbon Thin Film Chemical Sensors

LANL and collaborators are developing SAW devices for the rapid and reversible detection and measurement of organic compounds in the vapor 
UCRL-ID-118561

page 43 of 50

and solution phases. Species specific coatings for the reversible binding of chemicals of interest are being developed utilizing cyclodextrin inclusion compounds that are chemically bound to the SAW device surface.

Multispectral Neutron Logging: A New Generation Pulsed-Neutron Induced Gamma-Ray Multispectral Logging System for In Situ Mapping of Contaminants

LANL is developing two nuclear borehole logging techniques for the identification and mapping of contaminants. The second technique involves passive gamma-ray logging. Data correction and deconvolution algorithms are being developed to quantify this technique.

In Situ RCRA Metals Analysis

LANL is building a prototype system for the laser induced breakdown spectral characterization and measurement of $\mathrm{Cr}, \mathrm{Pb}, \mathrm{As}, \mathrm{Se}, \mathrm{Sb}, \mathrm{Cd}, \mathrm{Zr}, \mathrm{U}, \mathrm{Be}$, and $\mathrm{Th}$. This system utilizes fiber optics to guide laser energy to a sample, which is vaporized. A return fiber collects the plasma emission, which is analyzed for element specific spectral lines.

Direct Measurement of $\mathrm{Sr}^{90}$ in Surface Soils in Real-Time

PNL is developing a fiber based scintillator system for the measurement of high energy beta particles for the detection of the $2.28 \mathrm{MeV}$ beta decay of $Y^{90}$, daughter of $\mathrm{Sr}^{90}$. The stacked configuration allows the discrimination between events due to high and low energy beta particles, and cosmic or gamma rays. Custom electronics for the detection and analysis of signals from the fiber sensor are being designed and tested.

Sensor Characterization SupportQ.5-Q.10

Advanced Sciences, Inc. has published a series of reports identifying those chemical, radiochemical, and physical sensors suitable for use on characterizing and monitoring wastes at DOE sites. One report, task 6 (reference Q.5), is specific to the cone penetrometer.

Moisture Measurements by Electromagnetic Induction

PNL has been developing a moisture probe for in tank deployment utilizing the changes in sample impedance with moisture content. The probe uses two coils, one an EM transmitter, one a receiver, to measure the moisture of waste material in a 60 inch radius. 
Transuranic Elements and Moisture Measurement in High-Level Waste Tanks by Neutron Activation

PNL is designing a cone penetrometer specific probe for measuring the neutron flux and therefore transuranic content of tank wastes. The probe utilizes a copper metal probe, which is activated to the beta emitters $64,66 \mathrm{Cu}$. The induced activity of the copper is directly correlated to the neutron flux in the tank.

Sensing of Head Space Gases: Continuous In Situ Monitoring of gaseous Components in Underground Storage Tanks using Piezoelectric Thin Film Resonators

Ames lab is developing surface acoustic wave devices specifically for UST gases, hydrogen in particular. These microbalance devices are fabricated from gas sorbent specific coated thin film resonators composed of aluminum nitride on silicon substrates.

\section{Laser Induced Fluorescence Imaging}

EG\&G E/EM is developing a handheld laser induced fluorescence (LIF) for the detection of depleted uranium, VOCs, fuels, and plant stress. A gated, intensified CCD is used to collect the long lived phosphorescence from uranic compounds. Accompanying software and electronics are also being developed.

\section{Innovative Investment AreaQ.4}

\section{Assessment of Subsurface VOCs Using a Chemical Microsensor Array}

The University of Michigan, Ann Arbor is developing SAW devices for VOC identification and measurement. Coated devices can detect VOCs down to 5 $\mathrm{ppm}$, and pattern-recognition algorithms allow the identification of compounds with $95 \%$ confidence.

Fiber Optic Raman Spectrograph for In Situ Environmental Monitoring

EIC Laboratories have developed and demonstrated a fieldable fiber optic Raman probe and spectrograph. The probe is a filtered design for the removal of fiber Raman and laser line at the probe head, resulting in the transmission of sample Raman only to the spectrograph. The spectrograph is an echelle type, with no moving parts, coupled to a CCD camera. 
Remote Fiber-Optic TLD Monitoring System

International Sensor Technology is developing a remote thermoluminescence dosimetry (TLD) system for monitoring radiation fluxes remotely. The TLD is read by a $1 W$ nearIR laser pulse, which heats the sensor to $300^{\circ} \mathrm{C}$ and results in emission from radiation induced defects. The signal is transmitted via fiber optics to a detector system.

Field Raman Spectrograph for Environmental Analysis

EIC Laboratories has designed and tested a field hardened fiber optic Raman system. the system is equipped with either a Raman or Surface Enhanced Raman filtered probe. The Raman probe was designed with a side viewing head for incorporation into ARA's cone penetrometer.

Laser Spark Spectroscopy for Continuous Metal Emissions Monitoring

SNL is designing a laser induced atomic emission spectrometer for use with off gas from thermal treatment systems. Chemometric software is being evaluated for the identification of individual atomic species.

Electrochemical Sensor for Heavy Metals in Groundwater: Phase IIInstrument Development and Field Demonstration

Tufts University is developing an IC based twenty element array for the low $\mathrm{ppb}$ to high $\mathrm{ppm}$ detection of heavy metals in water. The sensor arrays are based upon a previously demonstrated mercury coated iridium ultramicroelectrode ( $\mathrm{Hg} / \mathrm{IrUME})$.

Fiber Optic Flow Probe

University of Washington, Seattle, is developing a microflow fiber optic sensor for chemical sensing. A capillary tube with dimensions similar to a fiber optic shall be utilized to deliver reagent to the probe tip, where colorimetric interaction of an analyte will be probed. 
UCRL-ID-118561

page 46 of 50

\section{APPENDIX C: $\quad$ COMMERCIALLY AVAILABLE SENSORS}

(*'s denote wide variety in sensors)

(For sources see references R.I - R.4)

\section{Hydrogen}

EIT, 251 Welsh Pool Road, Exion, PA 19341

(800) $872-8008$

Sensidyne, 16333 Bay Vista Drive, Clearwater, FL

34620 (800) 451-9444

(Below addresses available in Sensors 1990 Buyers Guide)

Ametek, Inc., U.S. Gauge Div.

Balzers, High Vacuum Products Div.

Bascom-Turner Instruments

Bionics Instrument Co., Ltd.

Broadley-James Corporation

Brooks Instrument

Control Instruments Corp.

EEV Inc.

Erdco Engineering Corporation

Figaro USA, Inc.

GfG America Gas Detection, Ltd.

Gow-Mac Instrument Co.

Henderson Engineering, Sahara Air Dryer Division

Infrared Fiber Systems, Inc.

International Sensor Technology

Leeds \& Northrup, A Unit of General Signal

Meterial Control, Inc.

Matheson Gas Products

MDA Scientific Inc.

Micro Pneumatic Logic, Inc.

Microsensor Technology, Inc.

Milton Roy, Process Analytical Division

Mitsubishi Int'l Corp./Shibaura Electronics Co.

MSA, Instrument Division

Perkin-Elmer Corp., Applied Science Division

Perma-Cal Corporation

Philips Components, Discrete Products Division

Rel-Tek Corporation

Sensor Solid State Services

Sentex Sensing Tecbnology, Inc.

Shokai Far East Ltd.

Sieger Gasalarm

Syprotec Corp.

Teledyne Analytical Instruments

Thomas Products Ltd., Flow Switch Div.

Transducer Research, Inc.

Ammonia or Ammonium Ion

Daigger Catalog 1994, (800) 621-7193 Page 141

EIT, 251 Welsh Pool Road, Exton, PA 19341

(800) $872-8008$

Sensidyne, 16333 Bay Vista Drive, Clearwater, FL

34620 (800) 451-9444

*Omega pH Catalog, (800) 826-6342 Page D16

(Below addresses available in Sensors 1990 Buyers Guide)

Ametek, Inc., U.S. Gauge Div.

Broadley-James Corporation

Capital Controls Co., Inc.

Fiatron Systems Inc.

Gam Rad West, Inc., Subsidiary of Gam Rad, Inc.

Henderson Engineering, Sahara Air Dryer Division

Ingold Electrodes, Inc.

Innovative Sensors Inc. 
Leeds \& Northrup, A Unit of General Signal

Mircoelectrodes, Inc.

Radiometer America Inc., Analytical Div.

Sensor Solid State Services

Solomat Intrumentation

TBI, A Division of Bailey Controls Co.

Thomas Products Ltd., Flow Switch Div.

Van London Company, Inc.

\section{Nitrate}

Daigger Catalog 1994, (800) 621-7193 Page 141

EIT, 251 Welsh Pool Road, Exton, PA 19341

(800) 872-8008

Sensidyne, 16333 Bay Vista Drive, Clearwater, FL

34620 (800) 451-9444

*Omega pH Catalog, (800) 826-6342 Page D16

(Below addresses available in Sensors 1990 Buyers Guide)

Ametek, Inc., U.S. Gauge Div.

Broadley-James Corporation

Capital Controls Co., Inc.

Fiatron Systems Inc.

Gam Rad West, Inc., Subsidiary of Gam Rad, Inc.

Henderson Engineering, Sahara Air Dryer Division

Ingold Electrodes, Inc.

Innovative Sensors Inc.

Leeds \& Northrup, A Unit of General Signal

Mircoelectrodes, Inc.

Radiometer America Inc., Analytical Div.

Sensor Solid State Services

Solomat Intrumentation

TBI, A Division of Bailey Controls Co.

Thomas Products Ltd., Flow Switch Div.

Van London Company, Inc.

Volatile Organic Compounds (VOC)

Daigger Catalog 1994, (800) 621-7193 Page 141

EIT, 251 Welsh Pool Road, Exton, PA 19341

(800) 872-8008

Thermo Environmental Instruments Inc.

8 West Forge Parkway, Franklin, MA 02038

(508) $520-0430$

Sensidyne, 16333 Bay Vista Drive, Clearwater, FL 34620 (800) $451-9444$

\section{Total Carbon}

\section{Cyanide}

Daigger Catalog 1994, (800) 621-7193 Page 141

EIT, 251 Welsh Pool Road, Exton, PA 19341

(800) 872-8008

Sensidyne, 16333 Bay Vista Drive, Clearwater, FL 34620 (800) 451-9444

*Omega pH Catalog, (800) 826-6342 Page D16

(Below addresses available in Sensors 1990 Buyers Guide)

Ametek, Inc., U.S. Gauge Div.

Broadley-James Corporation

Capital Controls Co., Inc.

Fiatron Systems Inc.

Gam Rad West, Inc., Subsidiary of Gam Rad, Inc.

Henderson Engineering, Sahara Air Dryer Division

Ingold Electrodes, Inc.

Innovative Sensors Inc.

Leeds \& Northrup, A Unit of General Signal 
Mircoelectrodes, Inc.

Radiometer America Inc., Analytical Div.

Sensor Solid State Services

Solomat Intrumentation

TBI, A Division of Bailey Controls Co.

Thomas Products Lid., Flow Switch Div.

Van London Company, Inc.

pH

*Daigger Catalog 1994, (800) 621-7193 Page 193-41

*Omega pH Catalog, (800) 826-6342 Whole Thing

Myron L Co., (619) 931-9189

Extech Instruments Corp., (617) 890-7440

(Below addresses available in Sensors 1990 Buyers Guide)

Ametek, Inc., U.S. Gauge Div.

Bailey Controls Co.

Barnant Co, A Division of Cole-Palmer

Bionics Instrument Co., Ltd.

Broadley-James Corp.

Capital Controls Co., Inc.

Chemfet Corp.

Cole-Parmer Instrument Co.

Dancer Communications, Inc.

Devar Inc.

Engineered Systems \& Designs

Fiatron Systems Inc.

The Foxboro Company

Gam Rad West, Inc., Subsidary of Gam Rad, Inc.

George Fischer Signet, Inc.

Great Lakes Instruments, Inc.

Henderson Engineering, Sahara Air Styer Division

Ingold Electrodes, Inc.

Innovative Sensors, Inc.

Lakewood Instruments

Laser Science, Inc.

Leeds \& Northrup, A Unit of General Signal

Microelevtrodes, Inc.

Radiometer America Inc., Analytical Div.

Rosemount Analytical Inc.

Sensorex

Solomat Instrumentation

TBI, A Division of Baily Controls Co.

Testoterm Inc.

Thomas Products Lid., Flow Switch Div.

Thornton Associates, Inc.

Triad Technologies

Universal Enterprises, In.

Van London Company, Inc.

\section{Temperature}

Daigger Catalog 1994, (800) 621-7193 Page 201-3

*Omega Temperature (Catalog coming), (800) 826-6342 Whole Thing

Luxtron Pamphlet (408) 727-1600

(Below addresses available in Sensors 1990 Buyers Guide)

Barksdale Controls, A Division of Imo Industries Inc.

Degussa Corporation, Temperature Sensing Department

EG\&G International, Inc., Moisture and Humidity Systems Div.

Fenwal Electronics, Inc.

Hy-Cal Engineering, A Unit of General Signal

Industrial Sensors \& Instruments, Inc.

J.P. Technologies

Jumo Process Control, Inc.

Micron Instruments

Ohmic Instruments Company 
Sigmund Cohn Corp.

Thermometrics, Inc.

ACR Systems, Inc.

Alpha Thermistor, Inc.

Dale Electronics, Inc.

Lextron

Mamac Systems

Pacific Sensors, Inc.

Temp-Pro Inc.

Temperature Measurement Systems

Temperature Specialists, Inc.

Temptronic Corporation

Texas Instruments, ISD Division

Also, see Multipurpose Sensors

\section{Humidity}

General Eastern Pamphlet, (800) 225-3208

*Omega pH Catalog, (800) 826-6342 Section L

(Below addresses available in Sensors 1990 Buyers Guide)

EG\&G International Inc. Moisture and Humidity Systems Div.

Hy-Cal Engineering, A Unit of General Signal

Jumo Process Control, Inc.

Ohmic Instruments Company

Thunder Scientific Corporation

Aartec Instruments, Inc.

Hygrometrix, Inc.

Infrared Fiber Systems, Inc.

Integrated Chemical Sensors Corporation

Kaye Instruments

Texas Instruments, ISD Division

TSI Incorporated

Weiss Instruments Inc.

Westinghouse Electric Corp., Comdustion Control Division

Also, see Multipurpose Sensors

\section{Pressure}

Omega Pressure Catalog, (800) 826-6342 Whole Thing

(Below addresses available in Sensors 1990 Buyers Guide)

Barksdale Controls, A Division of Imo Industries Inc.

Celesco Transducer Products

Copal Electronics (U.S.A.), Inc.

Dresser Industries, Inc., Heise Instrument Division

Eaton Corporation, Lebow Products

Industrial Sensors \& Instruments, Inc.

Jumo Process Control, Inc.

Kaman Instrumentation Corporation, Measuring Systems Group

Novasensor

Ohmic Instruments Group

Schlumberger Industries, Statham Transducer Division

Sensotec, Inc.

T-Hydronics Inc.

WIKA Instrument Corporation

Also, see Multipurpose Sensors

\section{Proximity}

*Opcon Industrial Sensors Catalog, (800) 426-9184

Aromat Corporation, (800) 228-2350

SICK Optic-Electronic, Inc. (Catalog coming) (800) 325-7425

Hermetic Switch, Inc. (Catalog coming) (405) 224-4046

(Below addresses available in Sensors 1990 Buyers Guide)

Brunswick Instrument

Capacitec, Inc.

The Fredericks Company, A Division of Inductotherm Industries

Kaman Instrumentation Corporation, Measuring Systems Group 
Locon Sensor Systems, Inc.

MTS Systems Corporation, Sensors Division

Schlumberger Industries, Statham Transducer Division

Sensor Engineering Company

Sensotec Inc.

Spectra Symbol Co.

Vitec, Inc.

Wabash Magnetics

Channel Industries Inc.

Digital Design, Industrial Vision Div.

Fiberoptic Systems, Inc.

\section{Radiation (Beta and Gamma)}

Hi-Q Environmental (Catalog coming) (619) 549-2820

Kurz Instruments Inc. (Catalog coming) (800) 424-7356

(Below addresses available in Sensors 1990 Buyers Guide)

Capintec Instruments, Inc., Division of Capintec, Inc.

Dosimeter Corporation

Eberline Instrument Corporation

EG\&G Berthold

GE Reuter-Stokes, Inc.

Health Physics Instruments, Division of Far West Technology

LaGrange Instruments, Inc.

LND Inc.

Ludlum Measurements, Inc.

Measurex

Nuclear Associates

Ohmart Corporation

Radiatino Monitoring Devices, Inc.

Rexon Components, Inc.

Shokai Far East Ltd.

Tennelec/Nucleus Inc.

TGM Detectors, Inc.

Thomson \& Nielsen Electronics Ltd.

Victoreen, Inc.

\section{Elemental Analysis}

(Strontium, Yttrium, Mercury, Technetium, Plutonium)

\section{Multipurpose Sensors}

[Fiber Optic Spectrometers: UV, VIS \& NIR] Ocean Optics, Inc. Pamphlet (813) 733-2447

[Temperature and Pressure] Geoguard Pamphlet

(716) 798-5597

[Temperature and Humidity] HyCal, 9650 Telstar Ave,

El Monte, CA 91731

[Optical Sensors] Terrascope Systems, Inc.

Catalog coming (510) 440-8040 